\title{
Article \\ A Multi-Analytical Approach for the Characterization of Seventeenth Century Decorative Wall Paintings in Two Norwegian Stave Churches: A Case Study at Eidsborg and Heddal, Norway
}

\author{
Ashley Amanda Freeman ${ }^{1, *(\mathbb{D})}$, Lavinia de Ferri ${ }^{2}$, Joy Mazurek ${ }^{3}\left(\mathbb{D}\right.$, Fabrizio Andriulo ${ }^{2}$ and Chiara Bertolin $^{1, *(\mathbb{D})}$ \\ 1 Department of Mechanical and Industrial Engineering, Norwegian University of Science and Technology, \\ Richard Birkelands vei 2B, Gløshaugen, 7491 Trondheim, Norway \\ 2 Department of Collection Management-Museum of Cultural History, University of Oslo, Kabelgaten 34, \\ 0580 Oslo, Norway; 1.de.ferri@khm.uio.no (L.d.F.); fabrizio.andriulo@khm.uio.no (F.A.) \\ 3 Getty Conservation Institute, Science Department 1200 Getty Center Drive, Suite 700, \\ Los Angeles, CA 90049, USA; JMazurek@getty.edu \\ * Correspondence: ashley.a.freeman@ntnu.no (A.A.F.); chiara.bertolin@ntnu.no (C.B.)
}

check for updates

Citation: Freeman, A.A.; de Ferri, L.; Mazurek, J.; Andriulo, F.; Bertolin, C. A Multi-Analytical Approach for the Characterization of Seventeenth Century Decorative Wall Paintings in Two Norwegian Stave Churches: A Case Study at Eidsborg and Heddal, Norway. Appl. Sci. 2021, 11, 3477. https://doi.org/10.3390/app11083477

Academic Editor: Emanuela Bosco

Received: 24 February 2021

Accepted: 9 April 2021

Published: 13 April 2021

Publisher's Note: MDPI stays neutral with regard to jurisdictional claims in published maps and institutional affiliations.

Copyright: (c) 2021 by the authors. Licensee MDPI, Basel, Switzerland. This article is an open access article distributed under the terms and conditions of the Creative Commons Attribution (CC BY) license (https:// creativecommons.org/licenses/by/ $4.0 /)$.

\begin{abstract}
The presented research examines 17th century distemper paint from the polychrome wooden interiors of two Norwegian stave churches: Eidsborg and Heddal. For the first time, the inorganic and organic components of specimens from Eidsborg and Heddal were identified using X-ray Diffraction (XRD), Environmental Scanning Electron Microscopy (ESEM) —Energy Dispersive X-ray Spectroscopy (EDS), Fourier-Transform Infrared (FT-IR) spectroscopy, Enzyme-Linked Immunosorbent Assay (ELISA), and Gas Chromatography-Mass Spectrometry (GC-MS) after derivatization. This multi-analytical approach allowed for the identification of red ochre as the main red pigment within the topcoat (with the possible addition of minium), confirmed that a chalk basecoat was used, and finally permitted the recognition of alteration phases. Markers of proteinaceous material attributed to the use of animal-based glues were detected throughout the stratigraphic layers of both churches, with the addition of linseed oil in some locations. Furthermore, the wood substrate showed markers characteristic of pine tree, with contamination of wood fractions being detected in some of the paint samples from Heddal and Eidsborg. This research has contributed to a better understanding of the current preservation state of Heddal and Eidsborg, and ultimately assisted in developing a deeper comprehension and awareness of materials used in Norwegian stave churches.
\end{abstract}

Keywords: 17th century wall paintings; pigment analysis; binder analysis; Norwegian stave churches; wooden polychrome; distemper paint; GC-MS; XRD; FT-IR; ELISA

\section{Introduction}

During the Middle ages, it is thought that over 1000 stave churches were erected throughout Norway, however currently only 28 remain (Figure 1). Of these remaining stave churches only two-thirds still have a decorative polychrome wooden interior; throughout the centuries wall paintings were washed away, removed, or even overpainted, depending on what was in fashion [1,2]. The majority of these remaining paintings date from the 17th and 18th centuries, and were rendered in a distemper technique [3]. The present study provides for the first time characterization of materials used within the polychrome wall paintings of two of the remaining Norwegian stave churches, Eidsborg and Heddal, whilst also adding to new knowledge about the wall painting technique used in Norwegian stave churches. 


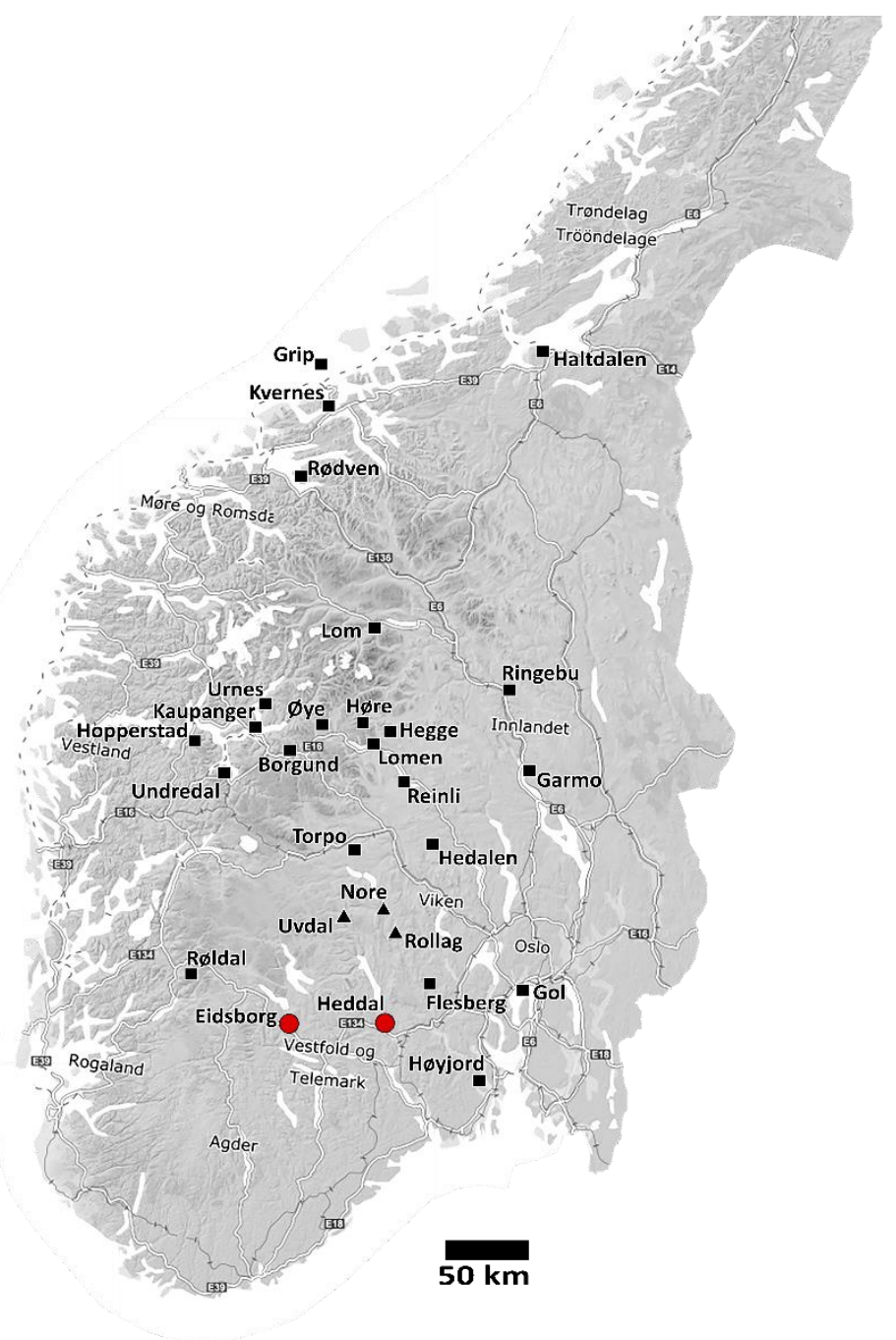

Figure 1. Map of the 28 remaining Norwegian stave churches, where the red circles denote churches examined in the present case study. Map is adapted from the website of Kartverket (the Norwegian Mapping Authority).

\subsection{Stave Church Palette}

Most 17th and 18th century Norwegian distemper paintings contain white and black pigments, along with various red, brown, yellow, blue, and green hues [4]. The variation in the distemper décors' tonality was often achieved through pigment mixtures [1], with the colorant ranging from inorganic (e.g., ochre and minium) to organic (e.g., kermes or madder lake) [4]. To date, pigment characterization has focused on both Norwegian secular buildings and churches [3,5], with 10 pigments being chemically identified (Table S1, see Supplementary Material). The pigments of Heddal and Eidsborg stave church have yet to be fully characterized; however, pigment assumptions have been reported [6-8] (Table S2, see Supplementary Material).

X-ray diffraction (XRD) is commonly used for pigment identification of painted artworks. It has been successfully applied for the analysis of artists' materials [9], painted artworks (e.g., murals, indigenous paintings etc.) [10-12] and reconstructions [13,14], as well as examining the mineralogical composition of modern [12,15-18] and historic $[15,19,20]$ ochres. The majority of these studies employ a multi-analytical approach, relying on a combination of XRD with various techniques including Scanning Electron Microscopy (SEM) $[12,16,19,20]$, thermal analysis $[11,16,18]$, Raman Spectroscopy $[9,14,20]$, and Fourier Transform Infrared Spectroscopy (FT-IR) $[9,11,14,16,19]$. Regrettably, the interpretation of IR spectra can be convoluted by overlapping features on account of different com- 
pounds within a multi-component sample, such as artists' materials. For this reason, a multi-technique approach coupling several analytical methods is normally followed when studying paint layers.

\subsection{Binding Media of Stave Church Artists}

The primary technique used by 17th century Norwegian stave church artists has been confirmed as distemper, where the main binding material is an animal-based adhesive, which is occasionally modified [3]. In this previous study, chemical characterization was only performed on specimens from three stave churches: Nore, Rollag, and Uvdal (see triangles in Figure 1). Additionally, as all remaining stave churches have undergone reconstructions, as well as restoration and/or conservation treatments, modifications to the pictorial image is a reasonable assumption.

In the cultural heritage field, the presence of proteins is often investigated using FT-IR, however, differentiating between animal species is not achievable. Often chromatographic methods are employed for this task [21-31], although techniques such as gas chromatography-mass spectrometry (GC-MS) consumes relatively large amounts of the sample (e.g., 0.1 to $5 \mathrm{mg}$ [32]). Additionally, animal species identification cannot be achieved directly with this technique, hydrolyzation of proteins into amino acids must occur first. Furthermore, amino acid analysis by means of GC-MS is not appropriate for analyzing mixtures of proteins, which are commonly encountered when examining historic paint specimens. Although when GC-MS analysis is carried out in conjunction with Enzyme-linked immunosorbent assay (ELISA), modifications to the binder can be fully investigated.

\subsection{A Case Study at Eidsborg and Heddal}

In the early 2000s, the Norwegian Institute for Cultural Heritage Research (NIKU) assumed responsibility for preserving the polychrome nave of Heddal and Eidsborg (see red circles in Figure 1). These two churches (Figure 2) are thought to have been constructed in the 13th century $[33,34]$ and have undergone multiple structural and decorative changes. Consequently, the churches' current interior décor was rendered centuries after the churches were constructed. Whereas the nave of Eidsborg was rendered in 1604 and 1640/49 [7], Heddal's nave is comprised of 17th century distemper décor rendered on top of a medieval design $[6,8]$. Additionally, the naves of both churches were retouched in the 20th century [6-8]; however, neither the retouching material nor the specific areas were documented. Additionally, in the following century, as part of the Stave Church Preservation Programme (2002-2016), specific areas of the polychrome wooden walls of Eidsborg and Heddal were consolidated using sturgeon glue. However, in 2013, flaking was observed in some of these consolidated areas [35]. This was surprising, as only recently have these treatments been unsuccessful; since the early 1990s, sturgeon glue has been the primary consolidant for flaking distemper paint within stave churches [1]. On September 27th, 2018, as part of the Sustainable Management of heritage Buildings in a Long-term perspective (SyMBoL) project, a sampling campaign was performed. This three-year project (2018-2021), coordinated by the Norwegian University of Science and Technology (NTNU), has aimed to provide evidence-based results to better inform strategies for the safe display of polychrome wood in stave churches. The restoration and conservation treatments mentioned in this subsection have been compiled in Table 1, whereas additional information regarding structural and interior changes can be found in Supplementary Material (Table S3). 

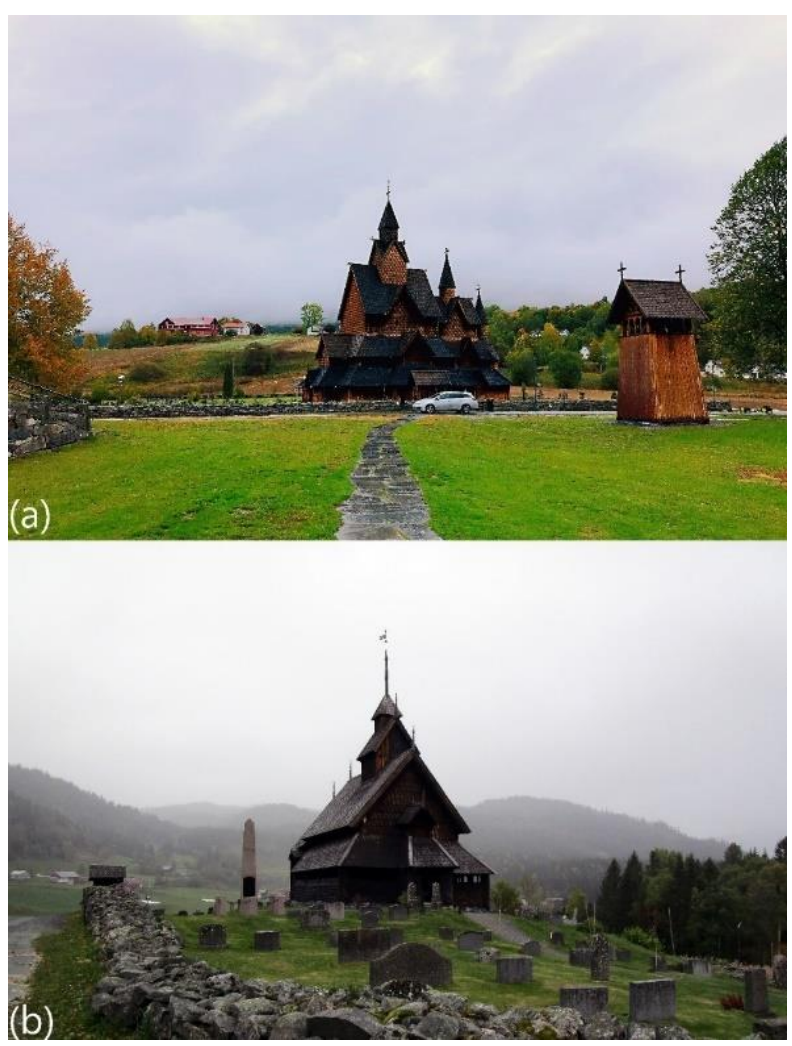

Figure 2. Case study of two stave churches in Vestfold and Telemark county: (a) Heddal and (b) Eidsborg.

Table 1. Restoration and conservation treatments.

\begin{tabular}{|c|c|c|c|c|c|}
\hline & Construction & Décor & $\begin{array}{l}\text { Restoration Treatment; } \\
\text { Retouching }\end{array}$ & $\begin{array}{l}\text { Conservation Treatment; } \\
\text { Consolidation with } \\
\text { Sturgeon Glue }\end{array}$ & References \\
\hline Heddal & $1200 s$ & $\begin{array}{l}\text { 1600s on top of a } \\
\text { medieval décor }\end{array}$ & $1950 \mathrm{~s}$ & 2009 & {$[6,8,33,34]$} \\
\hline Eidsborg & $1250-1300$ & $\begin{array}{l}1604 \text { (northern } \\
\text { wall) and } 1640 / 49 \\
\text { (southern wall) }\end{array}$ & $1920 \mathrm{~s}$ & 2007 & {$[7,33,34]$} \\
\hline
\end{tabular}

The primary objective of the present case study is to identify the pigments and binder(s) used in the polychrome wall paintings within Eidsborg and Heddal. In addition, the relation between the conservation condition and chemical modifications of the specimens was investigated. To achieve this goal, historic paint samples were subjected to chemical and optical analysis to determine the composition, with a secondary aim of identifying similarities and differences between the two stave churches. XRD, SEM, and FT-IR were used to investigate the chemical properties of pigments found within the decorative wall paintings, whereas FT-IR, GC-MS, and ELISA provided information about the painting's binder and wooden wall planks, as well as the presence of other organic compounds (e.g., pine resin or oil). Lastly, due to limited time and resources, only a subset of the collected samples was analyzed using all the above-mentioned techniques.

\section{Materials and Methods}

A summary of the analytical techniques and samples examined during this case study can be found in Table 2 . 
Table 2. Sample details: summary of sample description and techniques used during this case study. Samples correspond to those displayed in Figure 3.

\begin{tabular}{|c|c|c|c|c|c|c|c|}
\hline Sample Code & Sample Stratigraphy & $\begin{array}{c}\text { Optical } \\
\text { Microscopy }\end{array}$ & XRD & $\begin{array}{c}\text { SEM and Optical } \\
\text { Microscopy } \\
\text { (Cross-Sections) }\end{array}$ & FT-IR & GC-MS & ELISA \\
\hline \multicolumn{8}{|c|}{ Samples collected from Heddal stave church } \\
\hline \multicolumn{8}{|c|}{ Treated with sturgeon glue and in good condition } \\
\hline H1a & $\begin{array}{l}\text { four-layered stratigraphy } \\
\text { (red, grey, orange, white) }\end{array}$ & $\checkmark$ & $\checkmark$ & $\checkmark$ & $\checkmark$ & $\checkmark$ & \\
\hline $\mathrm{H} 1 \mathrm{~b}$ & $\begin{array}{l}\text { four-layered stratigraphy } \\
\text { (red, grey, orange, white) }\end{array}$ & $\checkmark$ & $\checkmark$ & $\checkmark$ & $\checkmark$ & $\checkmark$ & \\
\hline H1c & $\begin{array}{l}\text { four-layered stratigraphy } \\
\text { (red, grey, orange, white) }\end{array}$ & $\checkmark$ & $\checkmark$ & & $\checkmark$ & $\checkmark$ & $\checkmark$ \\
\hline H1d & $\begin{array}{l}\text { three-layered stratigraphy } \\
\text { (red, grey, white) }\end{array}$ & $\checkmark$ & $\checkmark$ & $\checkmark$ & $\checkmark$ & $\checkmark$ & \\
\hline H1e & $\begin{array}{l}\text { four-layered stratigraphy } \\
\text { (red, grey, black, white) }\end{array}$ & $\checkmark$ & $\checkmark$ & & $\checkmark$ & & \\
\hline \multicolumn{8}{|c|}{ Untreated; samples which were not treated with sturgeon glue } \\
\hline $\mathrm{H} 2 \mathrm{a}$ & $\begin{array}{l}\text { three-layered stratigraphy } \\
\text { (red, grey, white) }\end{array}$ & $\checkmark$ & $\checkmark$ & $\checkmark$ & $\checkmark$ & & \\
\hline $\mathrm{H} 2 \mathrm{~b}$ & $\begin{array}{l}\text { four-layered stratigraphy } \\
\text { (red, grey, black, white) }\end{array}$ & $\checkmark$ & $\checkmark$ & & $\checkmark$ & & \\
\hline $\mathrm{H} 2 \mathrm{c}$ & $\begin{array}{l}\text { four-layered stratigraphy (red } \\
\text { and white, grey, red, white) }\end{array}$ & $\checkmark$ & $\checkmark$ & & $\checkmark$ & & \\
\hline $\mathrm{H} 2 \mathrm{~d}$ & $\begin{array}{l}\text { four-layered stratigraphy } \\
\text { (red, grey, orange, white) }\end{array}$ & & & & & & $\checkmark$ \\
\hline $\mathrm{H} 2 \mathrm{e}$ & $\begin{array}{l}\text { four-layered stratigraphy } \\
\text { (red, grey, orange, white) }\end{array}$ & & & & & & $\checkmark$ \\
\hline \multicolumn{8}{|c|}{ Treated with sturgeon glue and in poor condition } \\
\hline H3a & $\begin{array}{l}\text { five-layered stratigraphy (red } \\
\text { and white, grey, black, } \\
\text { orange, white) }\end{array}$ & $\checkmark$ & $\checkmark$ & & $\checkmark$ & $\checkmark$ & $\checkmark$ \\
\hline \multicolumn{8}{|c|}{ Samples collected from Eidsborg stave church } \\
\hline \multicolumn{8}{|c|}{ Treated with sturgeon glue and in good condition } \\
\hline E1a & $\begin{array}{l}\text { three-layered stratigraphy } \\
\text { (red, black, white) }\end{array}$ & $\checkmark$ & $\checkmark$ & $\checkmark$ & $\checkmark$ & $\checkmark$ & \\
\hline E1b & $\begin{array}{l}\text { two-layered stratigraphy (red } \\
\text { on white) }\end{array}$ & $\checkmark$ & $\checkmark$ & $\checkmark$ & $\checkmark$ & $\checkmark$ & \\
\hline E1c & $\begin{array}{l}\text { three-layered stratigraphy } \\
\text { (red, black, white) }\end{array}$ & $\checkmark$ & $\checkmark$ & $\checkmark$ & $\checkmark$ & $\checkmark$ & \\
\hline E1d & $\begin{array}{l}\text { two-layered stratigraphy (red } \\
\text { on white) }\end{array}$ & $\checkmark$ & $\checkmark$ & $\checkmark$ & $\checkmark$ & $\checkmark$ & \\
\hline E1e & $\begin{array}{l}\text { three-layered stratigraphy } \\
\text { (red, black, white) }\end{array}$ & $\checkmark$ & $\checkmark$ & & $\checkmark$ & $\checkmark$ & $\checkmark$ \\
\hline \multicolumn{8}{|c|}{ Untreated; samples which were not treated with sturgeon glue } \\
\hline E2a & $\begin{array}{l}\text { three-layered stratigraphy } \\
\text { (red, black, white) }\end{array}$ & $\checkmark$ & $\checkmark$ & $\checkmark$ & $\checkmark$ & $\checkmark$ & $\checkmark$ \\
\hline $\mathrm{E} 2 \mathrm{~b}$ & $\begin{array}{l}\text { three-layered stratigraphy } \\
\text { (red, black, white) }\end{array}$ & $\checkmark$ & & & $\checkmark$ & & \\
\hline $\mathrm{E} 2 \mathrm{c}$ & $\begin{array}{l}\text { three-layered stratigraphy } \\
\text { (red, black, white) }\end{array}$ & $\checkmark$ & $\checkmark$ & & $\checkmark$ & & \\
\hline E2d & $\begin{array}{l}\text { three-layered stratigraphy } \\
\text { (red, black, white) }\end{array}$ & $\checkmark$ & $\checkmark$ & & $\checkmark$ & & \\
\hline \multicolumn{8}{|c|}{ Treated with sturgeon glue and in poor condition } \\
\hline E3a & $\begin{array}{l}\text { two-layered stratigraphy (red } \\
\text { on white) }\end{array}$ & $\checkmark$ & $\checkmark$ & & $\checkmark$ & $\checkmark$ & $\checkmark$ \\
\hline
\end{tabular}

\subsection{Distemper Paint Samples under Investigation}

Micro-sized paint fragments were sampled from the nave of Heddal and Eidsborg; the sampling area was no larger than $100 \mathrm{~mm}^{2}$. These fragments were collected from flaking areas, or from regions which would not distract the observer, with all samples originating 
from red pigmented areas. In both churches, samples were taken from locations in different conservation conditions, as shown in Figure 3. Three categories of samples were collected: untreated samples in good condition (i.e., samples which have not undergone sturgeon glue consolidation), samples which have undergone sturgeon glue consolidation and are in good condition (i.e., further treatment not necessary), and samples which have undergone sturgeon glue consolidation and are in poor condition (i.e., further flaking or powdering was observed). Table 2 lists the specimens collected during the 2018 campaign; a total of 11 samples were taken from Heddal (Figure 3a), whereas 10 samples were collected from Eidsborg (Figure 3b,c). Additional information regarding samples collected during the 2018 campaign can be found in Supplementary Materials (Figure S1 and Table S4).
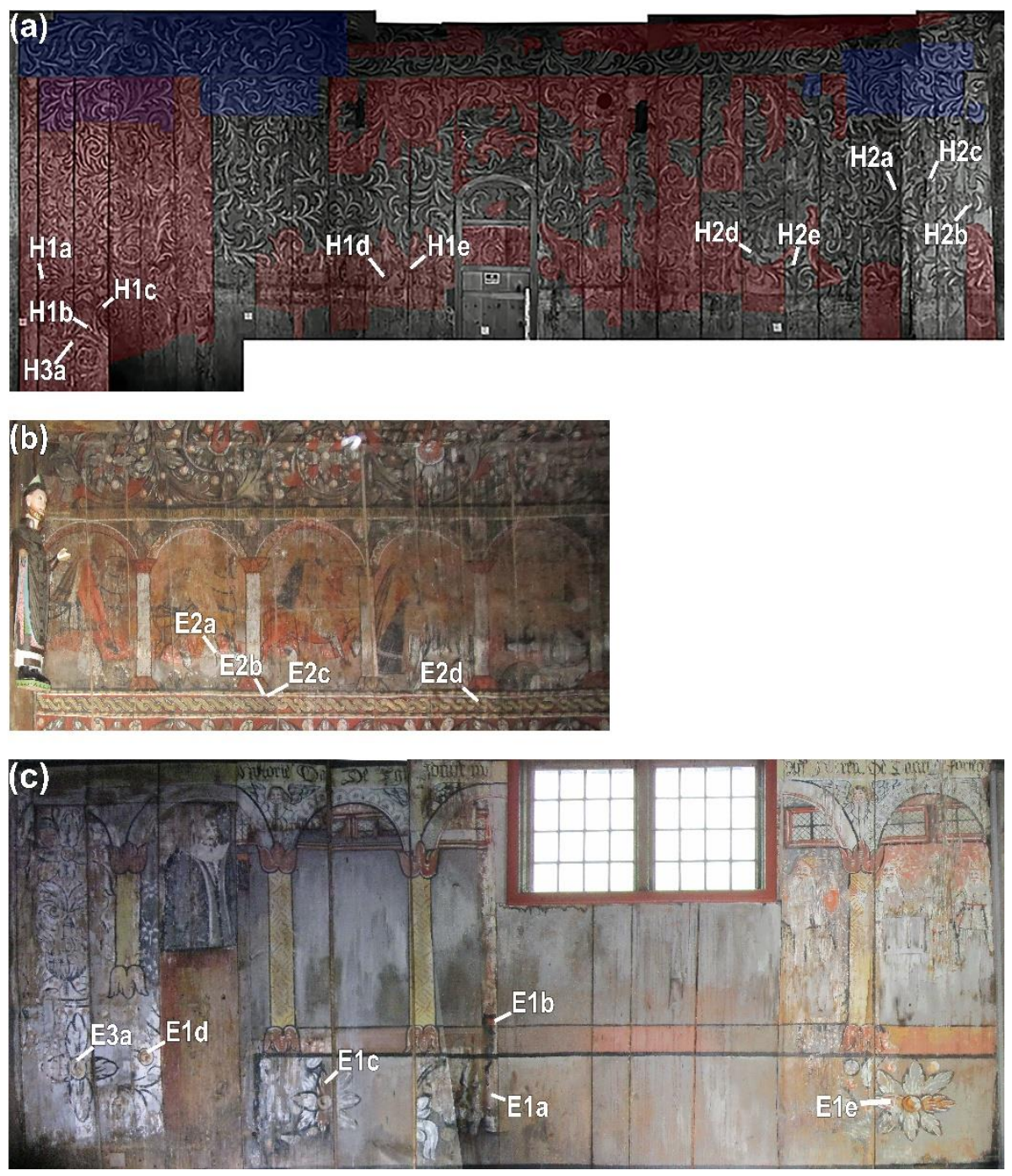

Figure 3. Maps of sampling points. (a) Heddal stave church, northern nave wall. Red denotes areas consolidated in 2009, whereas blue signifies areas of integrated wood and décor from the 1950s. (b) Eidsborg stave church, northern nave wall; (c) Eidsborg stave church, southern nave wall which was consolidated in 2007. Sample code and descriptions for both churches are compiled in Table 2. See Table S4 in Supplementary Material for sample area details. Treatment map from [8] was reproduced and modified with the permission of B. Wedvik, NIKU Rapport nr 121/2009.

\subsection{Microscopic Analysis: Optical Microscopy and Environmental Scanning Electron Microscopy-Energy Dispersive X-ray Spectroscopy}

Prior to preparing cross-sectional samples, the paint fragments were examined using a Keyence VHX -6000 Digital Microscope. Cross-sectional samples were prepared by 
embedding micro-size fragments of distemper paint in a one component acrylic-based resin (Technovit ${ }^{\circledR} 2000$ LC; Heraeus Kulzer, Germany). After the resin cured, the samples were dry polished using Micromesh ${ }^{\mathrm{TM}}$ polishing cloths, increasing in grit. The stratigraphy of these cross-sectional samples was investigated using a digital microscope (RH-2000, Hirox, Tokyo, Japan).

Backscattered Electron (BSE) images and elemental analysis of cross-sectional samples were obtained using an Environmental Scanning Electron Microscope (ESEM, Quanta 650 FEG, Thermo Fisher Scientific Inc., Waltham, MA, USA) equipped with an EDS system (Octane Pro, EDAX, Ramapo, NJ, USA). The uncoated cross-sectional samples were analyzed at $40 \mathrm{~Pa}$ (nitrogen), operating at $10 \mathrm{kV}$ with a working distance varying from 8.9 to $11.4 \mathrm{~mm}$ at environmental conditions.

\subsection{Fourier-Transform Infrared Spectroscopy}

Test specimens were divided into two parts, one to be analyzed using FourierTransform Infrared (FT-IR) Spectroscopy and the second to be examined by X-ray Diffraction. Infrared spectra were collected on a Bruker, Hyperion 3000 FT-IR between 4000$600 \mathrm{~cm}^{-1}$, with a resolution of $4 \mathrm{~cm}^{-1}$ and a total of 64 scans. Test specimens were analyzed after isolating particles from the stratigraphic layers, in which the particles were placed onto a diamond window and flattened using an anvil. All specimens were analyzed by means of transmission FT-IR. After which spectra corrections (baseline, atmospheric moisture, and carbon dioxide) were implemented using Omnic 7.1 software.

\subsection{X-ray Diffraction}

X-ray Diffraction (XRD) analysis was performed using a diffractometer (Rigaku Miniflex 600, Tokyo, Japan) with $\mathrm{Cu} K \alpha$ radiation $\mathrm{Cu} \mathrm{K} \alpha=1.54 \AA$, operating at $40 \mathrm{kV}$ and $15 \mathrm{~mA}$. Samples were scanned in the range of $2 \theta$ from $10^{\circ}$ to $70^{\circ}$ at $5^{\circ} / \mathrm{min}$ and step size of $0.02^{\circ}$. Characterization was performed on a single paint chip which was representative of the sample location; the topcoat and basecoat of each paint chip was examined, without further preparation, using a zero-background quartz holder. Diffraction patterns were interpreted using HighScore data interpretation software and crystalline phases were identified using the ICDD database.

\subsection{Gas Chromatography-Mass Spectrometry}

Paint fragments and wooden specimens were examined by Gas Chromatography (GC) using a $6890 \mathrm{~N}$ instrument (Agilent Technologies, Waldbronn, Germany) coupled with and a 5973-inset mass selective detector (Agilent Technologies, Waldbronn, Germany). When possible, the multi-layered paint samples were manually separated, resulting in paint specimens with an average weight of $388 \mu \mathrm{g}$, whereas the wooden specimens weighed between 207 and $515 \mu \mathrm{g}$ (Cahn Micro balance). GC-MS testing configuration and parameters are described in detail in [23], and are compiled in Supplementary Materials (Table S15). Specifically, the derivatization process described for identifying oils and resins, (Meth Prep II Protocol) and proteins (Amino Acid Protocol) from a single sample were followed.

Drying oils are identified in paint samples based on the concentration of palmitic $\left(C_{16: 0}\right)$, stearic $\left(C_{18: 0}\right)$, and azelaic $\left(C_{9}\right)$. Limited types of vegetable drying oils were available, thus fatty acid ratios were selected as a viable option for identification. However, fatty acids can be derived from various sources other than oils, such as animal glue and egg yolk. A commonly accepted approach for identifying a specific drying oil is by expressing the ratio of palmitic to stearic acid $\left(C_{16: 0} / C_{18: 0}\right)$ [36]. Nevertheless, as $C_{16}$ and $C_{18}$ are directly correlated, the ratio is considered to be unchanging. Generally, the $C_{16: 0} / C_{18: 0}$ ratio is a well-known value used in conservation science and has been established as the marker for different drying oils and egg (Table 3 ). However, when a mixture of drying oils, or egg and non-drying oils are both present, the interpretation of fatty acid profiles can be complicated. 
Table 3. $C_{16: 0} / C_{18: 0}$ values for drying oils and egg. Data from $[37,38]$.

\begin{tabular}{cc}
\hline & $\mathrm{C}_{\mathbf{1 6 : 0}} / \mathrm{C}_{\mathbf{1 8 : 0}}$ \\
\hline walnut oil & $2.5-3$ \\
poppy oil & $>3$ \\
linseed oil & $1-2.5$ \\
egg & $2.5-3.5$, if azelaic acid is below 0.5 \\
\hline
\end{tabular}

Additionally, the azelaic acid to palmitic acid ratio $\left(\mathrm{C}_{9} / \mathrm{C}_{16}\right)$ can be used to signify the presence of drying oils as opposed to egg lipids [21]. A $C_{9} / C_{16}$ ratio around 1 , or higher, indicates the presence of a drying oil, whereas values between 0.2 and 0.5 indicate egg yolk or semi-drying oils that only partially oxidize (e.g., sesame or grapeseed oil). Lipids such as fats, grease, and non-drying oils (e.g., castor or olive oil) have very low $C_{9} / C_{16}$ values (less than 0.2). Here, proteins are identified through a comparative method, in which the specimen's amino acids were compared to those of reference material [24,25]. A match is then established using correlation coefficients in which an identical match would result in a coefficient equal to 1.0. However, a correlation coefficient of 0.93 is often deemed as acceptable [23].

For this study, the percentage of protein was estimated using the sum of the weight percentages from the detected amino acids ( $\mathrm{mg} / \mathrm{mg}$ of amino acids in specimen). Stable amino acids were selectively analyzed, with this protocol yielding an underestimation of the per cent protein in the sample. L-norleucine was used as the internal standard and a blank (i.e., empty vial) was analyzed to monitor contamination during the analysis. For positively identifying the presence of fatty acids in the present study, a lower limit of two to three-times greater than the blank value was used. Here, fatty acid contamination from the glassware, or introduced by human contact, was observed at 1.65 and $2.35 \mathrm{ppm}$ for palmitic and stearic acid, respectively $\left(\mathrm{C}_{16} / \mathrm{C}_{18: 0}\right.$ ratio of 0.70$)$.

\subsection{Enzyme-Linked Immunosorbent Assay}

The Enzyme-Linked Immunosorbent Assay (ELISA) procedure used in this study has been discussed thoroughly in [22,39], and as such, only a brief description of the procedure will be given here. ELISA tests were performed on ground and multi-layered paint specimens ranging from 137 to $812 \mu \mathrm{g}$, with positive controls of paint reference materials prepared in a similar manner. The results were expressed as positive if the absorbency at $405 \mathrm{~nm}$ is above an optical density (OD) of 0.3 . In addition, false negatives can result if the selected antibodies do not recognize the protein. In this study, two collagen antibodies were used for this experiment. The collagen antibody (Abcam \#AB6577) used in the ELISA protocol is produced in rabbit, and will not react with rabbit skin glue, but it will react with all other mammal glues (cow, deer, pig, goat, etc.), and is weakly positive to fish glue. The fish collagen (Meridian Life Science \#T89171R) is weakly positive to mammal glues, but it will react strongly to fish glue.

\section{Results and Discussion}

The results obtained by XRD, EDS, FT-IR, GC-MS, and ELISA, for the polychrome decorative wall paintings, are summarized in Table 4 and Figures 4-9. Separate discussions on pigments, binding media, and wooden specimens are given in the following subsections. Lastly, these subsections mainly focus on the red topcoat and white basecoat. For the chemical composition of intermediate layers see Supplementary Material. 
Table 4. Summary of results from Enzyme-Linked Immunosorbent Assay (ELISA) and gas chromatography-mass spectrometry (GC-MS) analysis of historic paint samples and wooden specimen. Amino acid ratios $\left(\mathrm{C}_{16} / \mathrm{C}_{18: 0}, \mathrm{C}_{9} / \mathrm{C}_{16}\right.$, and $\left.\mathrm{C}_{18: 1} / \mathrm{C}_{18: 0}\right)$ and percentage of fatty acid (\%FA) of samples analyzed, where ND means not detected or below the detection limit. Correlation coefficient to animal glue and per cent protein (\% protein) based on the weight of the specimen. ELISA is reported as strongly positive if optical density (OD) $>0.45$ and weakly positive if $\mathrm{OD}<0.3$. See Supplementary Material for additional GC-MS data. Sample names correspond to those displayed in Figure 3 and listed in Table 2.

\begin{tabular}{|c|c|c|c|c|c|c|c|c|}
\hline & Sample Description & $\mathrm{C}_{16} / \mathrm{C}_{18: 0}$ & $\mathrm{C}_{9} / \mathrm{C}_{16}$ & $\mathrm{C}_{18: 1} / \mathrm{C}_{18: 0}$ & $\%$ FA & $\%$ Protein & $\begin{array}{c}\text { Correlation } \\
\text { Coefficient } \\
\text { (Animal Glue) }\end{array}$ & ELISA \\
\hline & Blank vial & 0.7 & - & - & - & - & - & - \\
\hline \multirow{3}{*}{ E1a } & White ground layer & 1.0 & - & - & ND & 5.6 & 0.98 & - \\
\hline & $\begin{array}{l}\text { Three layered sample } \\
\text { (red/black/white ground) }\end{array}$ & 0.9 & - & - & ND & 3.0 & 0.98 & - \\
\hline & Wood specimen & 1.0 & 1.0 & 0.2 & $\begin{array}{l}0.2 \% \text { fatty acid (oil) and } \\
\text { pine resin }\end{array}$ & 6.4 & 0.98 & - \\
\hline \multirow[t]{2}{*}{ E1b } & $\begin{array}{l}\text { Two layered sample } \\
\text { (red/white) }\end{array}$ & 1.5 & 0.7 & - & ND & 4.9 & 0.97 & - \\
\hline & Wood specimen & 1.2 & 1.9 & - & $\begin{array}{l}0.14 \% \text { fatty acid (oil) and } \\
\text { pine resin }\end{array}$ & 6.7 & 0.98 & - \\
\hline \multirow[t]{4}{*}{ E1c } & White ground layer & 1.6 & 0.2 & 0.6 & $\begin{array}{l}\text { Trace amounts of fatty } \\
\text { acids (oil) and pine resin, } \\
\text { most likely contamination } \\
\text { from the wood plank }\end{array}$ & 3.9 & 0.97 & - \\
\hline & $\begin{array}{l}\text { Bottom two layers } \\
\text { (black/white ground) }\end{array}$ & 0.8 & - & - & ND & 2.6 & 0.96 & - \\
\hline & $\begin{array}{l}\text { Top two layers } \\
\text { (red/black) }\end{array}$ & 0.8 & - & - & ND & 2.2 & 0.93 & - \\
\hline & $\begin{array}{l}\text { Three layered sample } \\
\text { (red/black/white ground) }\end{array}$ & 1.1 & 0.4 & - & $\begin{array}{l}\text { Trace amounts of fatty } \\
\text { acids (oil) and pine resin, } \\
\text { most likely contamination } \\
\text { from the wood plank }\end{array}$ & 3.3 & 0.98 & - \\
\hline \multirow{3}{*}{ E1d } & White ground layer & 1.0 & - & - & ND & 4.2 & 0.98 & - \\
\hline & Red top layer & 1.1 & 0.4 & - & ND & 3.8 & 1.00 & - \\
\hline & $\begin{array}{l}\text { Two layered sample with } \\
\text { insect (red/white) }\end{array}$ & 0.8 & - & - & ND & 0.0 & 0.37 & - \\
\hline \multirow{2}{*}{ E1e } & White ground layer & 1.2 & 0.4 & - & ND & 9.7 & 0.98 & Fish \\
\hline & $\begin{array}{l}\text { Three layered sample } \\
\text { (red/black/white ground) }\end{array}$ & 1.0 & 0.5 & - & ND & 5.0 & 0.98 & (strongly) \\
\hline \multirow[t]{2}{*}{ E2a } & $\begin{array}{l}\text { Three layered sample } \\
\text { (red/black/white ground) }\end{array}$ & 0.9 & 0.3 & - & ND & 3.8 & 0.99 & $\begin{array}{c}\text { Fish } \\
\text { (strongly) }\end{array}$ \\
\hline & Wood specimen & 1.1 & 1.4 & - & $\begin{array}{l}0.13 \% \text { fatty acid (oil) and } \\
\text { pine resin }\end{array}$ & 5.1 & 0.99 & - \\
\hline \multirow{2}{*}{ E3a } & White ground layer & 1.1 & - & - & ND & 3.7 & 0.98 & Fish \\
\hline & $\begin{array}{l}\text { Two layered sample } \\
\text { (red/white ground) }\end{array}$ & 1.1 & 0.3 & - & ND & 2.7 & 0.98 & (strongly) \\
\hline \multirow[t]{2}{*}{ H1a } & White ground layer & 0.9 & 0.4 & - & ND & 2.8 & 0.98 & - \\
\hline & $\begin{array}{c}\text { Four layered sample } \\
\text { (red/grey/orange/white) }\end{array}$ & 1.2 & 0.6 & - & $\begin{array}{l}\text { Trace amounts of fatty } \\
\text { acids (oil) and pine resin, } \\
\text { most likely contamination } \\
\text { from the wood plank }\end{array}$ & 4.7 & 0.99 & - \\
\hline \multirow{3}{*}{$\mathrm{H} 1 \mathrm{~b}$} & $\begin{array}{l}\text { White ground layer } \\
\text { White oround laver }\end{array}$ & 1.2 & 0.3 & - & ND & 10.8 & 0.99 & - \\
\hline & $\begin{array}{l}\text { trace amounts of orange } \\
\text { layer }\end{array}$ & 1.0 & - & - & ND & 7.1 & 0.99 & - \\
\hline & $\begin{array}{c}\text { Four layered sample } \\
\text { (red/grey/orange/white) }\end{array}$ & 1.4 & 0.6 & - & $\begin{array}{l}\text { Trace amounts of fatty } \\
\text { acids (oil) and pine resin, } \\
\text { most likely contamination } \\
\text { from the wood plank } \\
\text { Trace amounts of fatty } \\
\text { acids (oil) and pine resin, } \\
\text { most likely contamination } \\
\text { from the wood plank }\end{array}$ & 1.7 & 0.99 & - \\
\hline \multirow{3}{*}{$\mathrm{H} 1 \mathrm{c}$} & White ground layer & 1.1 & - & - & ND & 5.7 & 0.99 & $\begin{array}{c}\text { Fish } \\
\text { (weakly) }\end{array}$ \\
\hline & $\begin{array}{l}\text { Lower three layers } \\
\text { (grey/orange/white) }\end{array}$ & 0.9 & - & - & 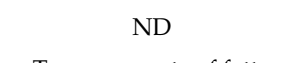 & 0.1 & 0.75 & - \\
\hline & $\begin{array}{c}\text { Four layered sample } \\
\text { (Red/grey/orange/white) }\end{array}$ & 1.6 & 0.7 & 0.5 & $\begin{array}{l}\text { Trace amounts of fatty } \\
\text { acids (oil) and pine resin, } \\
\text { most likely contamination } \\
\text { from the wood plank }\end{array}$ & 5.7 & 0.99 & $\begin{array}{c}\text { Fish } \\
\text { (strongly) }\end{array}$ \\
\hline \multirow{3}{*}{ H1d } & $\begin{array}{l}\text { Bottom two layers } \\
\text { (grey/white ground) }\end{array}$ & 1.0 & - & - & ND & 7.0 & 0.97 & - \\
\hline & $\begin{array}{l}\text { Top two layer } \\
\text { (Red/grey) }\end{array}$ & 1.1 & 0.4 & - & ND & 2.6 & 0.98 & - \\
\hline & Wood specimen & 1.3 & 0.8 & - & $\begin{array}{l}0.08 \% \text { fatty acid (oil) and } \\
\text { pine resin }\end{array}$ & 3.9 & 0.99 & - \\
\hline
\end{tabular}


Table 4. Cont.

\begin{tabular}{|c|c|c|c|c|c|c|c|c|}
\hline & Sample Description & $\mathrm{C}_{16} / \mathrm{C}_{18: 0}$ & $\mathrm{C}_{9} / \mathrm{C}_{16}$ & $\mathrm{C}_{18: 1} / \mathrm{C}_{18: 0}$ & $\%$ FA & $\%$ Protein & $\begin{array}{c}\text { Correlation } \\
\text { Coefficient } \\
\text { (Animal Glue) }\end{array}$ & ELISA \\
\hline $\mathrm{H} 2 \mathrm{~d}$ & $\begin{array}{c}\text { Four layered sample } \\
\text { (red/grey/orange/white } \\
\text { ground) }\end{array}$ & - & - & - & - & - & - & $\begin{array}{c}\text { Fish } \\
\text { (strongly) }\end{array}$ \\
\hline $\mathrm{H} 2 \mathrm{e}$ & $\begin{array}{l}\text { Four layered sample } \\
\text { (red/grey/orange/white } \\
\text { ground) }\end{array}$ & - & - & - & - & - & - & $\begin{array}{c}\text { Fish } \\
\text { (weakly) }\end{array}$ \\
\hline \multirow{3}{*}{ Н3а } & White ground layer & 1.1 & - & - & $\begin{array}{c}\text { ND } \\
\text { Trace amounts of fatty }\end{array}$ & 4.5 & 0.99 & \multirow{3}{*}{$\begin{array}{c}\text { Fish } \\
\text { (strongly) }\end{array}$} \\
\hline & $\begin{array}{l}\text { Lower three layers } \\
\text { (black/orange/white) }\end{array}$ & 1.3 & 0.3 & 0.3 & $\begin{array}{l}\text { acids (oil) and pine resin, } \\
\text { most likely contamination } \\
\text { from the wood plank }\end{array}$ & 6.6 & 0.98 & \\
\hline & $\begin{array}{c}\text { Top two layer } \\
\text { (red and white/grey) }\end{array}$ & 1.5 & 0.7 & - & $\begin{array}{c}\text { Trace amounts of fatty } \\
\text { acids (oil) }\end{array}$ & 5.4 & 0.97 & \\
\hline
\end{tabular}

(a)

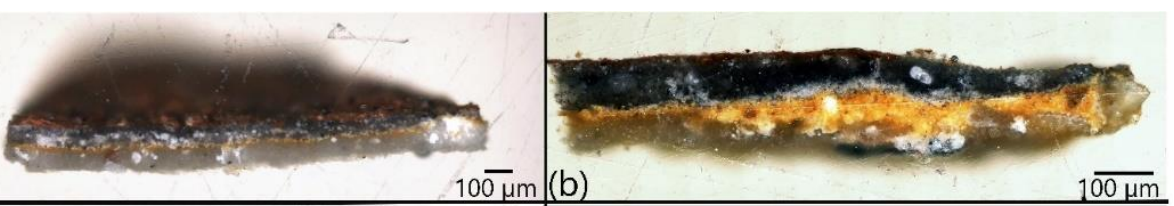

(e)

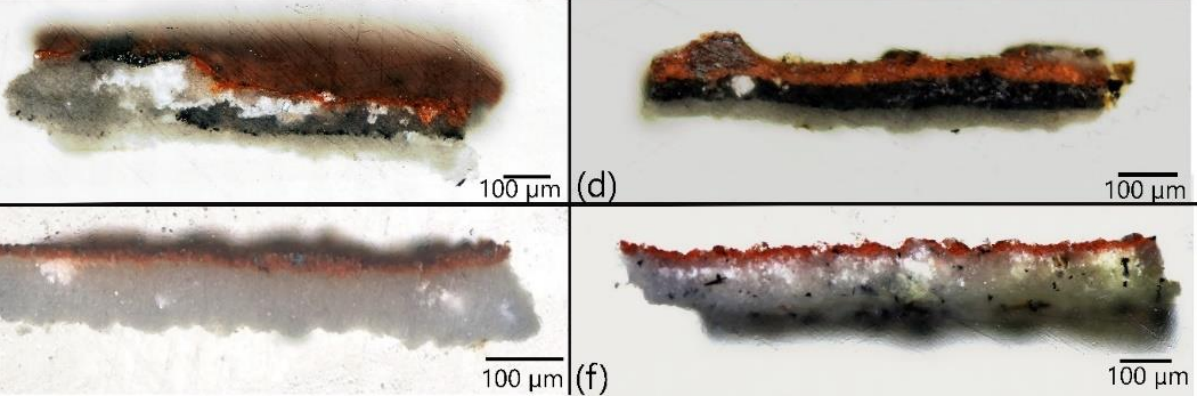

Figure 4. Optical images of cross-sectional samples from Heddal and Eidsborg, showing typical stratigraphy: (a) H1a, (b) H1b (c) H1d, (d) E1c, (e) E1d, and (f) E2a. Sample names correspond with those listed in Table 2 and displayed in Figure 3. See Supplementary Material for optical images of all cross-sectional samples (Figure S2).
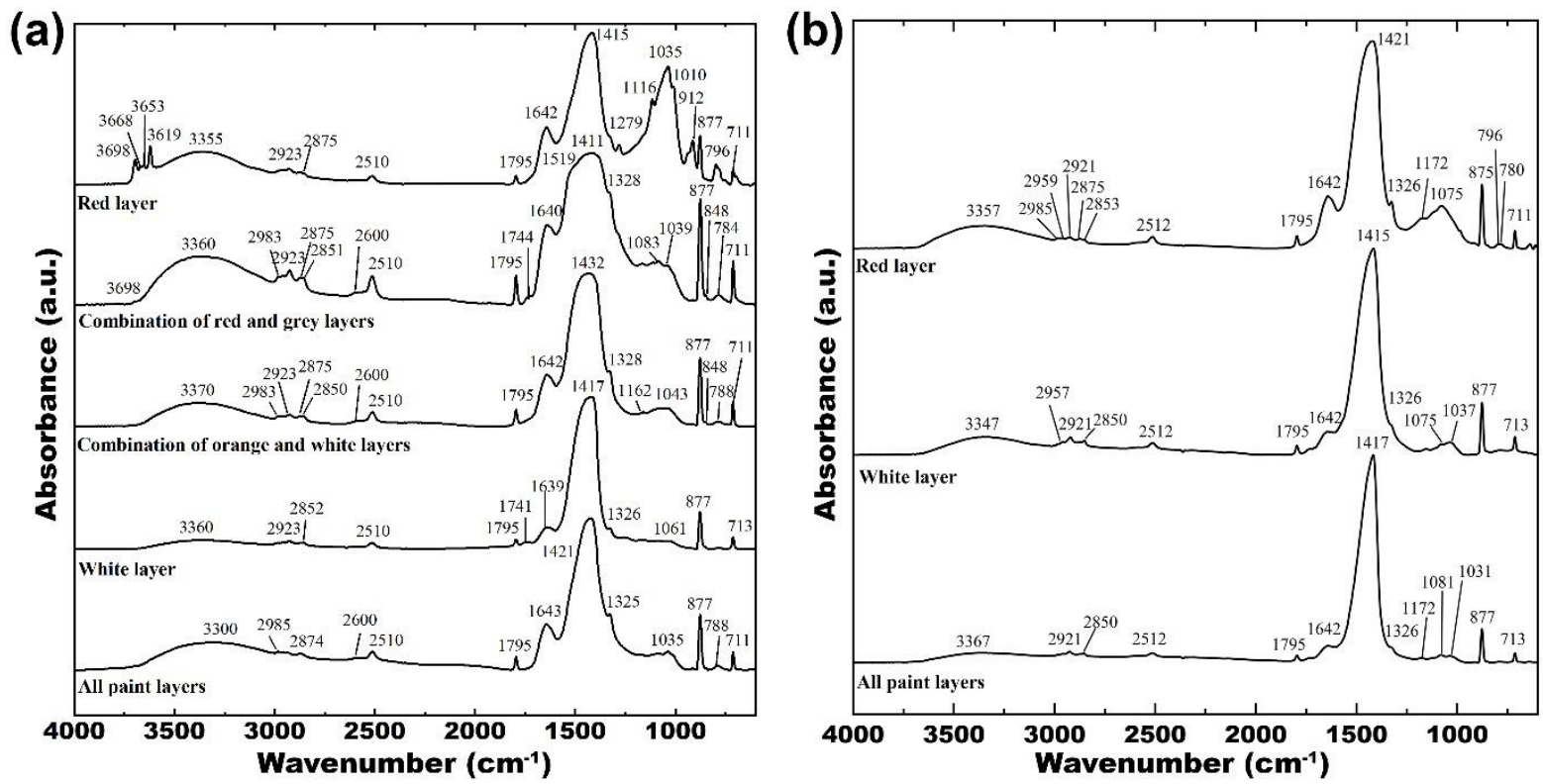

Figure 5. Fourier-Transform Infrared (FT-IR) spectra in the region 4000-600 $\mathrm{cm}^{-1}$ for (a) H1a and (b) E1a with layer isolation. Optical images of both cross sections can be found in Supplementary Information. See Supplementary Information for spectral interpretation of historic paint samples. 

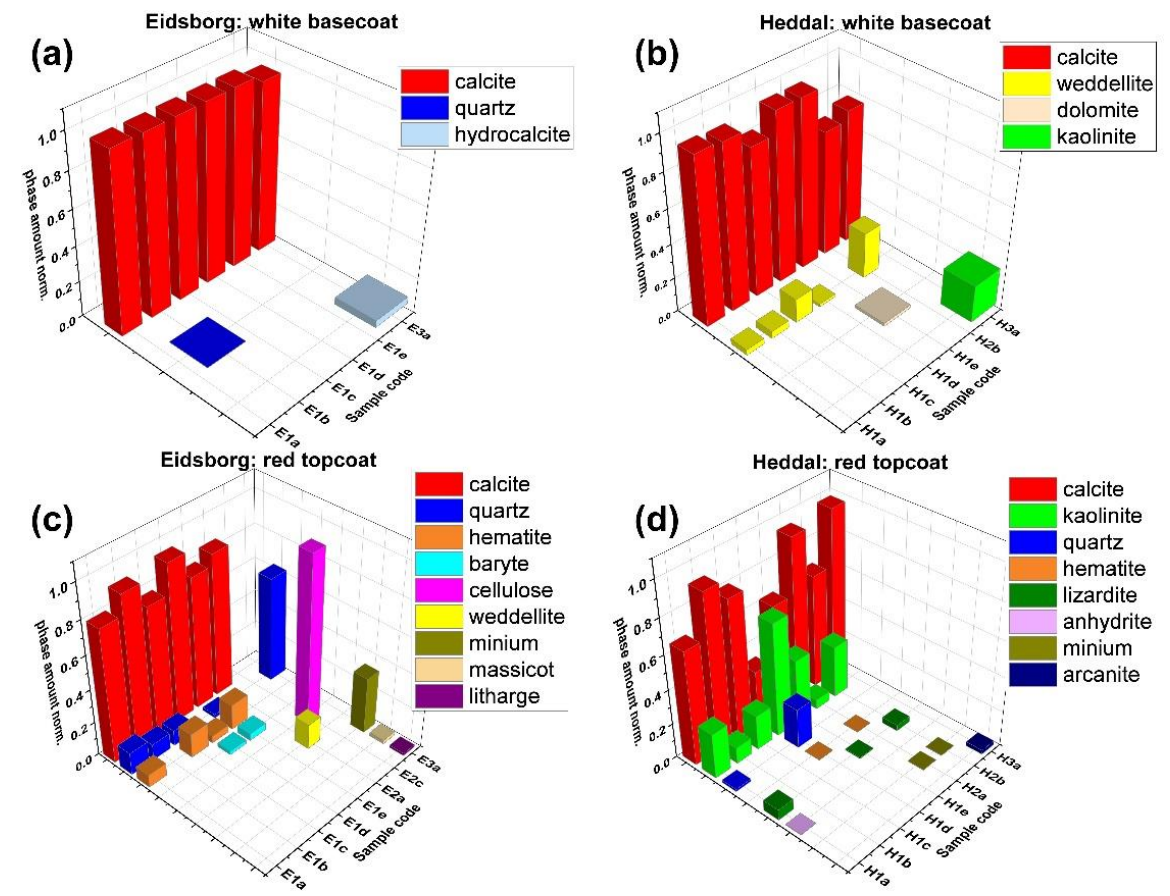

Figure 6. Semi-quantitative phase amounts of specimen from Heddal and Eidsborg by X-ray diffraction (XRD). (a) White basecoats in Eidsborg; (b) White basecoats in Heddal; (c) Red topcoat in Eidsborg; (d) Red topcoat in Heddal.

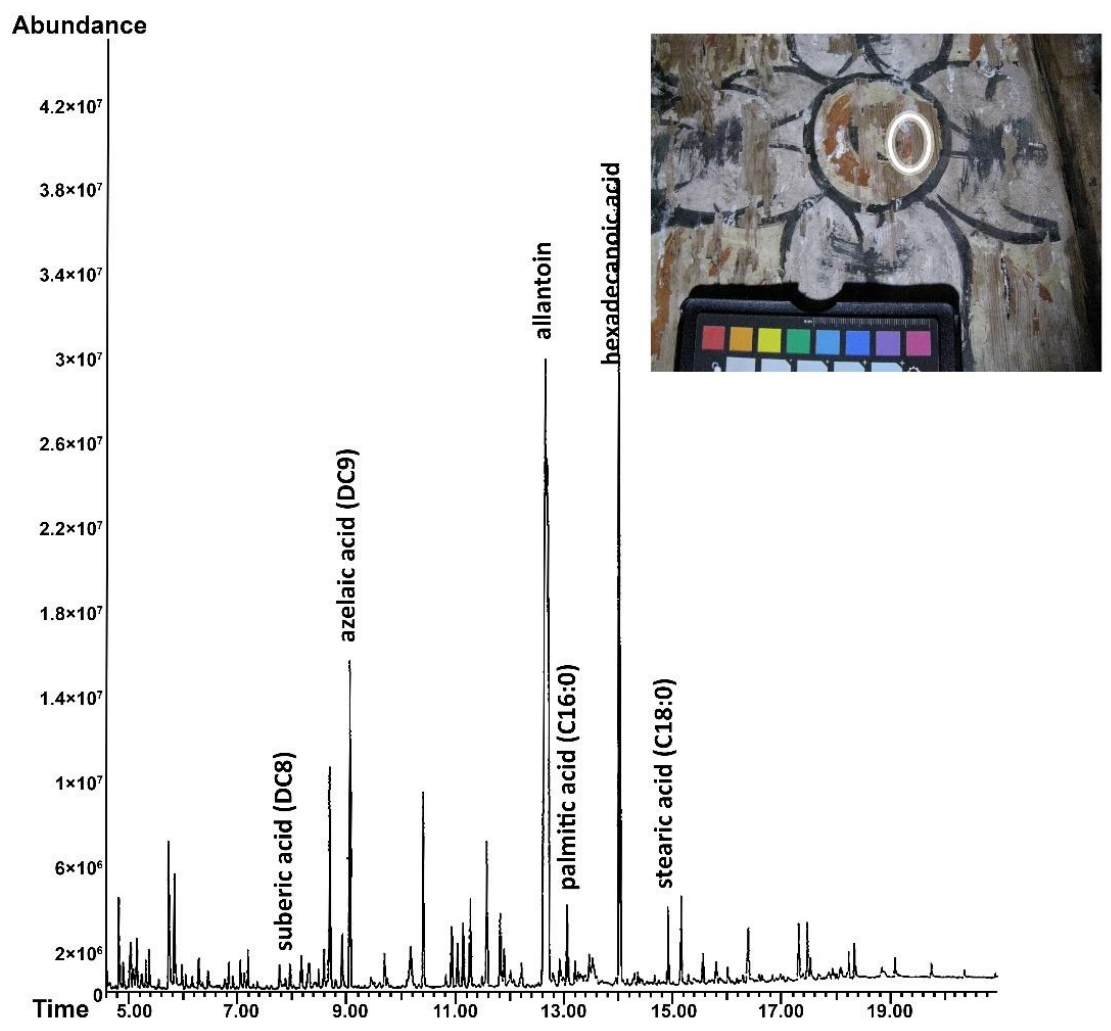

Figure 7. GC-MS chromatogram and image of sample location for E3a. Total ion chromatogram of white basecoat from E3a, highlighting the allantoin peak around 12.50. Circle within image denotes sample location. 


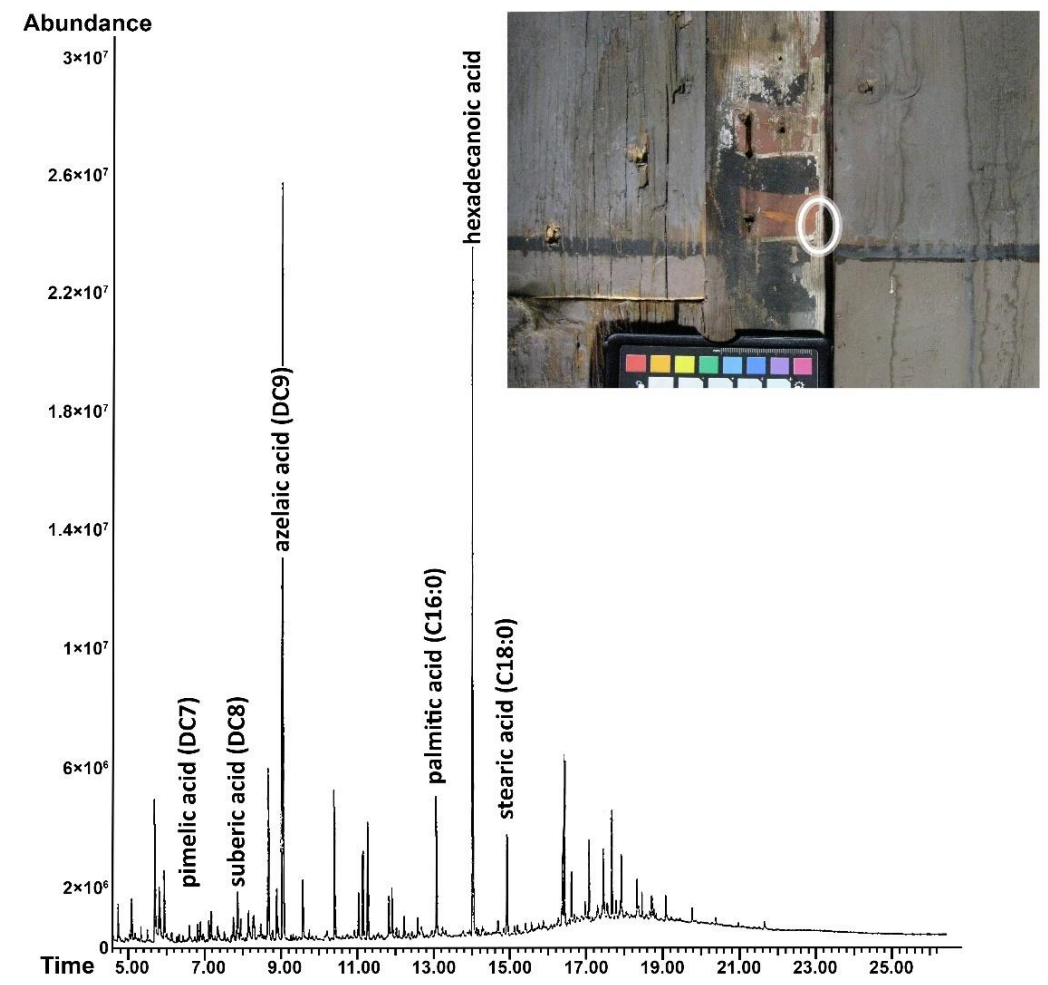

Figure 8. An example of the total ion chromatogram of paint specimen and image of sample location. Total ion chromatogram of paint specimen (E1b) showing characteristic peaks of pine resin around 16-19 min (i.e., abietic acid). Circle within image denotes sample location.

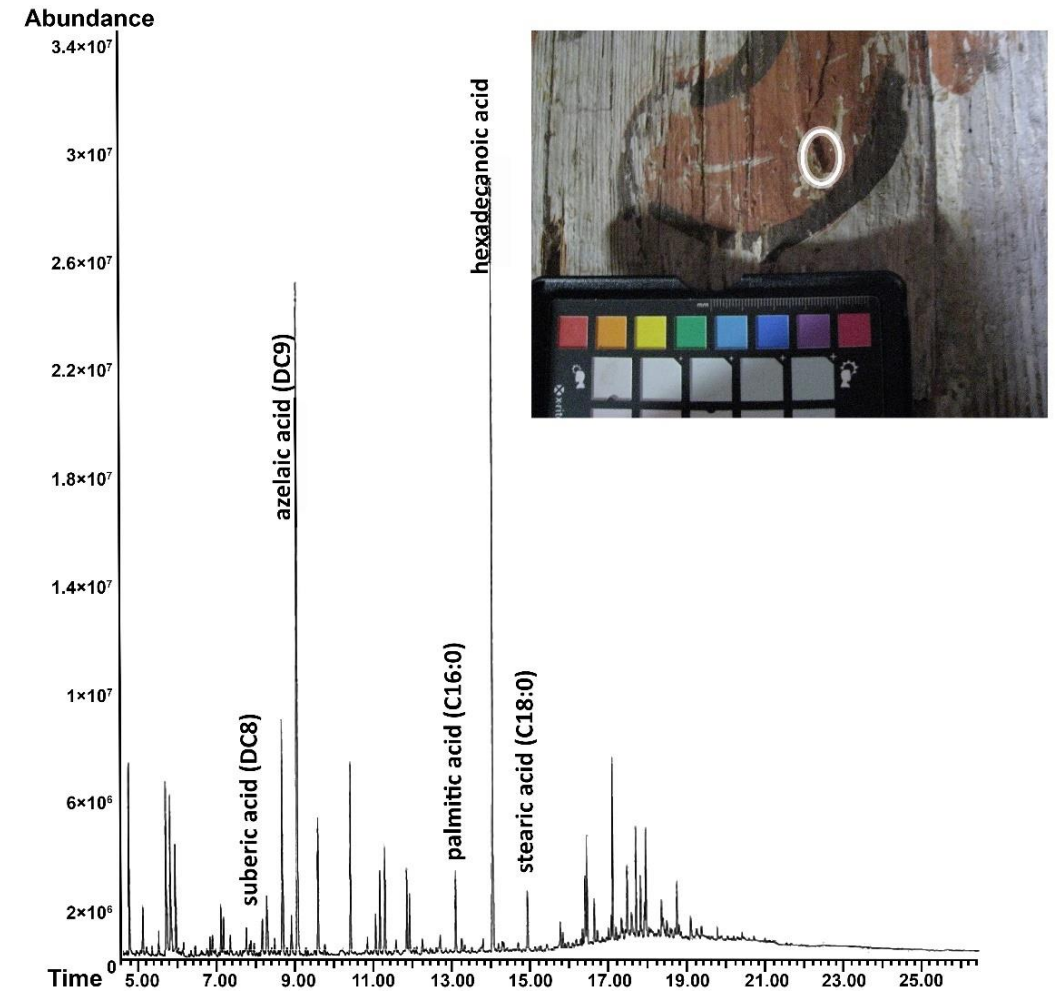

Figure 9. An example of the total ion chromatogram for wooden specimen and image of sample location. Total ion chromatogram of wood specimen (Hl1d) showing characteristic peaks of pine resin around 16-19 minutes (i.e., abietic acid). Circle within image denotes sample location. 


\subsection{Pigment Analysis}

\subsubsection{Stratigraphy}

The stratigraphic layers of representative paint fragments from each sampling location were examined with an optical microscope. All samples contained a red topcoat and white basecoat, with possible intermediate layers of orange, grey, or black paint. While the samples collected from Eidsborg were comprised of two or three layers of paint, in which the intermediate layer of black was always observed, samples from Heddal ranged from three to five layers, with intermediate layers of orange, grey, and/or black (Table 2). The stratigraphy of these samples illuminates the artists' method and is directly related to the sample location. Additional microscopic images of the collected specimen were captured under visible light (Figure S1, see Supplementary Material).

A subset of the paint fragments was prepared as cross-sectional samples, with the common stratigraphy shown in Figure 4. These cross-sectional samples suggest that the wooden planks were first prepared with a white ground layer, which is consistent with the distemper technique within stave churches [4]. Typically, this basecoat also acted as the background color [3,5] once dry the pictorial image was executed in a rapid manor so as not to re-solubilize the basecoat [1,4]. Additionally, the artists' process of mixing pigments is easily observed in the paint fragments from Heddal and Eidsborg (Figure S1, see Supplementary Material). See Figure S2 and Table S5 in Supplementary Material for images of all cross-sections and summary of layer thickness.

\subsubsection{Mineralogical and Chemical Compositions of the White Basecoat}

Analysis performed using XRD, ESEM-EDS, and FT-IR support the findings of Olstad and Solberg $[3,5]$ and confirm the pigment assumption cited in the conservation reports [6,7], that the basecoat is calcium carbonate-based (chalk). ESEM-BSE images (Figure S3, see Supplementary Material) either displayed a non-uniform porous matrix with micro-fossils (bioclasts) or fine particles distributed throughout the ground layer. The EDS results mainly consist of Ca which can be attributed to calcite from chalk, with minor concentrations of $\mathrm{Al}, \mathrm{Si}, \mathrm{Mg}, \mathrm{Pb}$, and Na probably deriving from impurities (Table $\mathrm{S6}$, see Supplementary Material) besides C, O, and N.

Figure 5 displays the typical FT-IR absorption bands for the historic paint, whereas the attribution to vibrational modes is compiled in Supplementary Material (Table S12). FT-IR spectra of all ground layers (see Supplementary Material) show the presence of high amounts of calcite, coupled with low quantities of silicates probably in the form of clay minerals. In many of the analyzed samples, a broadening of the main carbonate band $\left(v_{3}-\mathrm{CO}_{3}{ }^{2-}\right.$ asymmetric stretching mode) has been observed coupled with slightly pronounced shoulders. This could be interpreted as being due to small amounts of dolomite $\left(\mathrm{CaMg}\left(\mathrm{CO}_{3}\right)_{2}\right)$, even if modifications in the positions of the $v_{4}$ and $v_{2}$ peaks were not observed. It is known that the main carbonate band can be split into three sub-bands due to the distortion of the carbonate group, which is suggestive of an amorphous state. The $v_{3}$ position is mainly ruled by the stretching force constant of the $\mathrm{C}-\mathrm{O}$ bond with the lower wavenumbers being related to amorphous forms, while higher values are generally related to crystalline forms [40]. The simultaneous presence of several organic and inorganic phases (see following subsections) is responsible for the complexity of the spectra, resulting from overlapping features. Consequently, XRD patterns were collected to clarify the nature of the crystalline phases in the mixtures.

XRD analysis (Figure 6a,b) corroborates the SEM and IR findings, that calcite, with inclusion of other phases, is the main material used for the white basecoats. In Eidsborg (Figure 6a) small amounts of hydrocalcite $\left(\mathrm{CaCO}_{3} \cdot \mathrm{H}_{2} \mathrm{O}\right)$ were found in $\mathrm{E} 3 \mathrm{a}$, being the only consolidated sample in poor condition. Hydrocalcite has been found in natural deposits, as well as on frescos painted in a Portuguese semi-underground leisure room [41]. The presence of such a mineral is indicative of ongoing dissolution-recrystallization processes $[41,42]$. Furthermore, water damage has been observed on the southern nave wall of Eidsborg (e.g., tide lines) [7]. 
When examining samples taken from Heddal, the semi-quantitative analysis of XRD patterns shows relevant amounts of weddellite, a calcium oxalate di-hydrate mineral $\left(\mathrm{CaC}_{2} \mathrm{O}_{4} \cdot 2 \mathrm{H}_{2} \mathrm{O}\right)$ (Figure 6b). In particular, a consolidated sample in good condition (H1c) and unconsolidated sample ( $\mathrm{H} 2 \mathrm{~b})$ showed the largest amount of weddellite. Typically, the presence of this mineral phase is attributed to bacterial activity or a possible degradation process from past conservation treatments [43]. However, its presence in the unconsolidated sample $(\mathrm{H} 2 \mathrm{~b})$ suggests that the sturgeon glue consolidant has little to no connection with this alteration. Moreover, the presence of weddellite can be used as an index, showing the degradation state of the pictorial image (Figure 3a and Figure S7 in Supplementary Material). Lastly, the presence of kaolinite was only detected in $\mathrm{H} 3 \mathrm{a}$, the only consolidated sample from Heddal that was in poor conservation condition. These kaolinite features are possibly due to the interaction between the X-ray beam and the subsequent orange layer (Table 2), or it could signify a retouching. Retouching in Heddal was known to have occurred during the 1950s, especially in areas of red and white paint. However, the specific materials and locations were never recorded $[6,8]$.

\subsubsection{Mineralogical and Chemical Compositions of the Red Topcoat}

The EDS analysis of the red topcoat is suggestive of a Fe-based pigment such as an ochre possibly mixed with calcium carbonate. The common contributing elements detected in the red layer were $\mathrm{Fe}, \mathrm{Ca}, \mathrm{Al}$, and Si (Table S6, see Supplementary Material). If the red pigment within the artists' palette of Heddal and Eidsborg were comparable, the EDS analysis would display similar semi-quantitative results. However, the results from EDS and FT-IR analysis are varying. However, by using a multi-analytical approach these differences were characterized.

The main difference between the IR spectra from Heddal and Eidsborg was found in the features attributed to clay minerals (Figure 5 and Table S13 in Supplementary Material). FT-IR spectroscopy of the Heddal samples permitted the identification of kaolinite $\left(\mathrm{Al}_{2}(\mathrm{OH})_{4} \mathrm{Si}_{2} \mathrm{O}_{5}\right)$, thanks to the presence of four specific peaks located between $\sim 3620$ and $\sim 3700 \mathrm{~cm}^{-1}$. These four features, in the $\mathrm{OH}$ region, represent a peculiar characteristic of kaolinite and are due to stretching motions of the inner groups situated between the tetrahedral and octahedral layers $\left(\sim 3620 \mathrm{~cm}^{-1}\right)$ and on the octahedral surfaces [44]. The octahedral layers and surfaces tend to form hydrogen bonds with the oxygen atoms of the subsequent layer and lead to in-phase symmetric stretching vibrations $\left(\sim 3695 \mathrm{~cm}^{-1}\right)$ and to out-of-plane stretching motions $\left(\sim 3669\right.$ and $\left.\sim 3653 \mathrm{~cm}^{-1}\right)$. Whereas spectra of Eidsborg specimens showed features compatible with the presence of clay minerals whose attribution to a specific phase was not plausible, as only a few broad bands were identified. Except for kaolinite and dickite, FT-IR spectra of clay minerals are often not specific in the spectral interval between 850 and $1150 \mathrm{~cm}^{-1}$, frequently displaying one or two broad absorption bands. Additionally, in samples from both churches, a shoulder possibly related to small amounts of montmorillonite was found around $848-850 \mathrm{~cm}^{-1}$ [44], as well as quartz which is generally indicated by the typical doublet at $779-800 \mathrm{~cm}^{-1}$ [45] with the main band often masked by other very intense signals.

Some of the FT-IR spectra showed profiles differing from the common features obtained for the same typology of layer (e.g., red or white). This is the case of the red layer from E1c that displayed a pronounced broad band between 990 and $1290 \mathrm{~cm}^{-1}$ (Figure S6, see Supplementary Material). Such spectral regions host features compatible with those of a sulphate $\left(983,1087,1116\right.$ and $\left.1182 \mathrm{~cm}^{-1}\right)$, probably barite $\left(\mathrm{BaSO}_{4}\right)$ to which the two uncertain peaks at 611 and $638 \mathrm{~cm}^{-1}$ also seem to be attributable.

The semi quantitative analysis of XRD patterns of the red layers showed the presence of barite in E1d and E1e (Figure 6). Since XRD and FTI-R analysis were performed on different portions of samples (whole flakes for XRD and manually separated layers for FT-IR), a slight mismatch of results is possible. However, the recognition of barite features with two different techniques, in samples from the same church wall (Figure 3c), can be considered as a reliable indicator of its presence. Here, barite could be present as a natural 
impurity, as its appearance as an artist's pigment (i.e., barytes) occurred over a century after the rendering of this polychrome wall [46].

Additionally, a couple of other alteration phases were individuated from the diffraction pattern. Small amounts of anhydrite $\left(\mathrm{CaSO}_{4}\right)$ and arcanite $\left(\mathrm{K}_{2} \mathrm{SO}_{4}\right)$ were detected, and their presence can be accredited to interactions with environmental pollutants. Most of the XRD analysis gave evidence of the occurrence of minerals, such as calcite and quartz, in samples from both Eidsborg and Heddal (Figure 6c,d). However, analysis showed a significant difference between the red pigment used within the two sites. In particular, the distinctive diffraction pattern of kaolinite was only found in samples taken from Heddal (Figure 6d), confirming the FT-IR results (Table S13, See Supplementary Material). Additionally, trace amounts of other minerals were identified, such as lizardite $\left[\mathrm{Mg}_{3} \mathrm{Si}_{2} \mathrm{O}_{5}(\mathrm{OH})_{4}\right]$. This mineral belongs to the kaolin-serpentine group and is similar in structure to kaolinite, except for the octahedrally coordinated $\mathrm{Mg}$ ions that are settled in the octahedral sheet. For these samples, the presence of lizardite can be considered as an impurity in the original material or due to ongoing alteration processes mostly occurring on the extremities of the wall. The significant amount of lizardite is attributable to degradation phenomena affecting kaolinite in H1a and H2b, which both contain weddellite in the basecoat (see Section 3.1.2).

XRD analysis (Figure $6 c, d$ ) confirmed the presence of hematite in both sites, supporting the EDS results (Table S6, see Supplementary Material). The main difference between the XRD data of these two churches is in the relative amounts of such pigment; the semiquantitative analysis of patterns suggests that greater amounts of red pigments were present in samples from Eidsborg (Figure 6c), where only traces of hematite were identified in Heddal's samples (Figure 6d). This is probably related to the way the analysis was performed. Generally, the red layer of the Heddal samples is thinner, with the contributing factors from the previous layers being more relevant. The final effect is that of a dilution.

Additionally, minium was individuated in samples from both churches (Figure 6c,d); only traces of $\mathrm{Pb}_{3} \mathrm{O}_{4}$ and hematite were found in samples $\mathrm{H} 1 \mathrm{~d}, \mathrm{H} 2 \mathrm{a}$ and $\mathrm{H} 2 \mathrm{~b}$, while samples E2d and E3a showed considerable relative amounts of minium $(\sim 33.6 \%)$, associated to other $\mathrm{Pb}$-oxides such as Litharge and Massicot (tetragonal and orthorhombic $\mathrm{PbO}$, respectively). Red ochre and minium have previously been identified in the pictorial layer of 1600-1700s and medieval stave church wall paintings, respectively [1]. However, combining minium and hematite was not mentioned in [1], although stave church artists during this period were known to mix pigments.

Finally, cellulose from the wooden substrate was the only compound observed for E2c (Figure 6c). This sample was extremely thin, not permitting the separation of the pictorial surface layer from the substrate (Figure S1, see Supplementary Material). Consequently, both the XRD pattern and the FT-IR spectrum acquired on the surface of the paint layer only showed cellulose contributions.

\subsection{Analysis of Binding Media and Wood Specimens}

\subsubsection{Analysis of Paint Sample: Natural Plant Resins and Oils}

GC-MS analysis showed evidence of a drying oil only in one sample (H3a, Table 4); the $C_{16} / C_{18: 0}$ value (1.5) obtained for the top two layers of H3a agrees with the values previously reported for linseed oil [38]. Drying oils have been identified at Uvdal and Rollag (ca. 1650s), however, when the oil was incorporated into the pictorial layer is unknown. The oil could have been from a previous conservation treatment or it could have been part of the original material [3]. During the 1600-1700s, linseed oil was accessible in larger Norwegian cities. However, for the artists at Heddal and Eidsborg, they would most likely need to transport all of their materials with them or have them delivered to the church site [1]. Therefore, it is more likely that these findings are suggestive of an area that was retouched by Sæeter in the 1950s [6,8]. As mentioned in Section 3.1.2, the specific materials used during this 20th century restoration were unknown; however, based on prior experience of retouching done by Sæter, it was assumed that a glue-based paint was used at Heddal. The findings presented here within suggest that retouching was also 
performed with oil. Furthermore, these findings support the results of [5], in which alkaline saponification analysis indicated the presence of oil in a Heddal sample.

GC-MS analysis can also be used to examine the presence of glycerol in a paint sample, if an abundant amount of oil is present. However, this is complicated by the fact that glycerol can also be derived from egg yolk [47]. For the samples examined, glycerol was not detected (Figure S8, see Supplementary Material). Additionally, if a whole egg were used, the lipid content of the untreated sample (E2a) would have been greater than $0.01 \%$.

Unlike the GC results, absorption bands indicative of oil were only identified in Eidsborg samples (Table S14 in Supplementary Material). Here, the IR absorption peak located near $1735-1745 \mathrm{~cm}^{-1}$ has been considered as discriminative for the presence of oil. However, as these IR results were not corroborated by the adopted chromatographic methods (Table 4), future studies will be conducted to clarify the use of drying oils at Eidsborg.

Finally, GC results also showed contamination to the paint layers. Allantoin, a product of urine, was found in the ground layer of E3a (Figure 7), but not in the upper layers. The most probable explanation of its presence is that it was excreted from a housefly before the artist applied the motif. Additionally, GC-MS (Table 4 and Figure 8) and IR (Table S14, See Supplementary Material) analysis of samples from both churches showed the presence of wood itself, or wood-derived products (e.g., resin), strongly indicating that the wooden planks are contaminating the painted layers. Additionally, in some cases, the spectral features almost completely mask absorption bands related to other compounds (e.g., E2b, Table S13 in Supplementary Material). As this case study focuses on polychrome wooden structures, it is not surprising that the acquired results included peaks readily assigned to wood.

\subsubsection{Analysis of Paint Sample: Egg, Animal Adhesive, and Casein (Proteins)}

GC-MS analysis identified amino acids in all specimens, although the amount varies from sample to sample. Hydroxyproline, which is indicative of animal glue, was found in all specimens (Table S16, see Supplementary Material). Additionally, glycine was the most abundant amino acid for all samples except for those from H1d and H3a, and one of the samples from E1d. These results are also suggestive of an animal-based glue, as glycine is the most abundant amino acid found in animal glues, whereas aspartic acid and serine, and glutamic acid and leucine are most abundant in egg and casein, respectively [48]. Most samples closely match the amino acids profile of animal glue, with a correlation coefficient ranging from 0.93-1.00 (Table 4). The two samples with the lowest correlation were the four layered sample from H1c and the two layered sample with insect from E1d, which resulted in correlation coefficients of 0.75 and 0.37 , respectively. If a paint specimen is comprised of a single binding medium (e.g., only bone glue) the correlation coefficient would be equal to 1.0, although values greater than 0.97 are considered acceptable [22] However, a significant reduction in the correlation coefficient occurs if the test specimen is composed of multiple proteins [26]. Here, the addition of the consolidant convolutes the interpretation of the amino acid analysis.

Previous analysis performed on specimens from Nore, Rollag, and Uvdal (triangles in Figure 1) confirmed that an animal-based adhesive was used as the main binding material, with occasional modifications [3]. At Nore and Uvdal, egg was identified in some of the blue pigmented areas, whereas casein was identified in the ground layer of Nore, Rollag, and Uvdal [3]. However, neither casein nor egg have been confirmed through additional analysis. Furthermore, casein used as a binding medium was not recorded in Norway until ca. 1750 [3], which is a little over a century after the polychrome paintings of Heddal and Eidsborg were rendered. Therefore, it is not surprising that neither egg nor casein were identified during this study.

Table 4 also reports the per cent protein obtained from the test specimens. No significant difference was observed between the protein content of the two sites, nor was a trend obtained within the three different sample categories. While the per cent protein of the specimen from Heddal ranged between 1.7 and 10.8\%, the samples from Eidsborg were 
composed of 2.2-9.7\% protein (when excluding E1d). Additionally, when comparing the average amount of protein within the white ground layer (basecoat), similar amounts were obtained $($ Heddal $=5.6+1.7 \%(n=4)$, Eidsborg $5.4+2.2 \%(n=5))$.

ELISA confirmed the presence of fish glue in all specimens (Table 4). See Supplementary Material for a summary of the absorbance values (Figure S9, see Supplementary Material). Most of the samples were strongly positive for fish glue (above $0.45 \mathrm{OD}$ ) and mammal glue was not detected (below 0.3 OD). Only two of the samples (ground layer of $\mathrm{H} 1 \mathrm{c}$ and paint layers of $\mathrm{H} 2 \mathrm{e}$ ) resulted in a weak positive for fish (around 0.4 OD). Absorbance intensity is directly correlated to the concentration of proteinaceous glue and can be affected by degradation (loss of tertiary structure) or cross linking with pigments. In addition, egg and casein antibodies were not utilized in this study and mixtures of proteins would be difficult to detect with GC-MS. Amino acid analysis is not always accurate, especially when mixtures of proteins are present because after hydrolysis, amino acids combine and lose their peptide signature. As such, the identification of egg and animal glue mixtures, based on amino acid analysis, could be misleading. Proteomics or immunological techniques are preferable for the identification of mixtures and can also be used for species identification.

Lastly, most of the FT-IR spectra displayed weak absorption peaks related to animal glue (Figure S6 and Table S14, see Supplementary Material). Additionally, when used in low amounts, animal glue features can easily be masked by inorganic phases. In particular, the peak at $\sim 2985 \mathrm{~cm}^{-1}\left(\mathrm{CH}_{3}\right.$ asymmetric stretching vibrations) has been considered as discriminative [49] and other bands compatible with the spectral profile of animal glue were typically identified. Among these features are amide groups, which are normally considered as being connected to proteinaceous materials (e.g., glues); unfortunately, due to overlapping of peaks referable to other functionalities of wood/wood-related compounds, it was not possible to utilize these features as unambiguous markers for glues. For example, structures often found around $1640 \mathrm{~cm}^{-1}$ can be attributed to $\mathrm{C}=\mathrm{O}+\mathrm{C}=\mathrm{C}$ vibrations of aromatic ketones due to wood [50], as well as to H-O-H bending motions in clays [44], and to the combination of $\mathrm{C}=\mathrm{O}-\mathrm{N}-\mathrm{H}$ stretching and $\mathrm{NH}_{2}$ bending vibrations in animal glue [51]. The same applies to the wide band often centered around $3350-3360 \mathrm{~cm}^{-1}$, where $\mathrm{OH}$ vibrations from wood-related materials can occur together with a combination of $\mathrm{N}-\mathrm{H}$ asymmetric stretching and $\mathrm{CH}_{2}$ stretching motions from glues.

\subsubsection{Analysis of Wood Specimens}

The wooden specimens (E1a, E1b, E2a, and H1d) showed the presence of palmitic, steric, and azelaic acids which are three fatty acids found in pine resin, as well as oil, with the fatty acid content ranging from 0.08 to $0.2 \%$ (Table 4 ). All wooden specimens showed characteristic peaks of pine resin around 16-19 minutes, mainly abietic acid, suggesting that these wooden planks were made from trees within the Pinaceae family (Figure 9). During the Middle Ages, Scots pine (Pinus sylvestris L.) was used as the principal building timber in Norway [33], as such it is plausible that pine was used for the interior walls of both Heddal and Eidsborg. In addition, the wood specimens displayed a high percentage of animal glue $(<3.9 \%)$ (Table 4$)$, which results from an isolation layer of glue that was applied before the basecoat (i.e., sizing), or from the basecoat itself. Unfortunately, there is no literature regarding the practice of sizing wooden wall planks within stave churches. However, sizing has been discussed in various treaties and manuals including "Il Libro dell'Arte" by Cennini, from the late 14th-15th centuries, as well as a Danish manual ca. 1794 [3], titled “Nye og Fuldstamdige Maler- og Forgylder-Bog”. Additionally, previous studies at Uvdal and Nore are suggestive of an isolation layer [3], so the use of an isolation layer at Heddal and Eidsborg is plausible. However, to clarify whether the animal glue detected on the wooden specimen is from the ground layer, or an isolation layer, requires further examination. 


\section{Conclusions}

For the first time, pigments and binding media from Heddal and Eidsborg stave church were characterized by a multi-technique approach. In addition, information related to the conservation condition of the painting material was obtained.

Pigment analysis presented in this study confirms the presence of ochre and chalk used in both Heddal and Eidsborg, with the XRD patterns confirming the presence of hematite as the main red pigment. Hematite was found to be coupled to the more precious minium in a few samples and in very different proportions between the two churches. While only traces of minium were found in two untreated samples from Heddal, quite high relative amounts were detected in the only consolidated sample in poor conservation condition taken from Eidsborg (E3a). EDS, FTIR and XRD analysis revealed the similarities between the elemental constituents found at Heddal and Eidsborg, whilst simultaneously emphasizing the subtle differences found in the clay components of the red pigments. These results suggest the use of different raw materials and/or different artists' recipes within the two sites.

Binding media analysis identified the presence of a proteinaceous material, i.e., animal glue, in all samples using GC-MS and FT-IR, with ELISA identifying fish glue in all tested specimens. Overall, these results concluded that distemper (i.e., animal glue-based paint) was used as the main technique in the nave of Heddal and Eidsborg; however, the use of oil was also identified. Within Heddal, this secondary binder was most likely used during past interventions. On the other hand, it was not possible to distinguish the original glue-based binder from the consolidant (sturgeon glue). Additionally, IR and GC-MS analysis showed the presence of wood and/or wood-related products through the paint layers, signifying that the wall planks are contaminating the pictorial image.

When examining the current preservation state of these two sites, XRD analysis of the white basecoat from Heddal showed evidence of ongoing alteration phenomena. In particular, the amount of weddellite was found to increase when moving from the left to the right of Heddal's northern nave wall. Furthermore, when examining the common painting materials (i.e., pigments and binders) used at these two sites, differences were mainly found in consolidated areas that were in poor condition (E3a and H3a). On the basis of the obtained results, we can presume that these areas would have been retouched during the 1920s and 1950s, for Eidsborg and Heddal, respectively. The specific mechanism of damage is uncertain; however, water seems to be the main contributing factor. Due to the inherent property of glues readily absorbing water, the most common cause of damage to distemper paint is due to environmental moisture or liquid water. It can facilitate the migration of mobile components, as well as the re-solubilization of the binder, which could ultimately weaken the cohesive and adhesive properties of the paint. Additionally, as the stave church's building envelope is not airtight, direct exposure to water is not uncommon; water damage was observed at both sites (e.g., dark shields or tide lines) during the 2000s consolidation campaigns. Thus, the results presented in this paper represent the foundation for ongoing research for the preservation and conservation of these unique and fragile artworks.

In conclusion, the presented paper aimed to provide a complete characterization of the materials constituting distempered paintings as well as alteration products of Heddal and Eidsborg stave churches through a multi-technique approach. The investigation focused on both the inorganic and organic fractions of the historic material and results clearly demonstrate the necessity of applying different analytical techniques to solve issues related to the identification of such complex mixtures. Specifically, further studies will be carried out to better investigate the presence and distribution of a secondary red pigment (minium), and to solve inquiries related to the identification of the specific animal species used to prepare the binder. 
Supplementary Materials: The following are available online at https:/ /www.mdpi.com/article/ 10.3390/app11083477/s1, Figure S1: Image of sample location within Eidsborg and Heddal and microscopic image of collected specimen. (Left image): Arrow identifying sample location prior to sampling, (Right image): microscope image of collected sample $(100 \times)$. Refer to Table S4 for numerical location of sampling and description, Figure S2: Microscopy images of cross-sectional samples from Heddal and Eidsborg: (a) H1a, (b) H1b, (c) H1d, (d) H1e, (e) H2a, (f) E1a, (g) E1b, (h) E1c, (i) E1d, and (j) E2a. Cross-sectional samples were prepared by embedding distemper paint fragments in Technovit ${ }^{\circledR} 2000$ LC (Heraeus Kulzer, Germany), Figure S3: SEM-BSE images of crosssectional from Heddal and Eidsborg: (a) H1a, (b) H1b, (c) H1d, (d) H1e, (e) H2a, (f) E1a, (g) E1b, (h) E1c, (i) E1d, and (j) E2a. See Figure S2 for microscopic image of cross-sectional samples, Figure S4: Spot analysis images of cross-sectional samples, Figure S5: EDS spectrum of historic paint samples from Heddal and Eidsborg, Figure S6: FT-IR spectrum in the region $4000-600 \mathrm{~cm}^{-1}$ for all samples, with layer isolation when possible, Figure S7: XRD patterns of samples from Heddal. The intensity increase in weddellite's signals is shown. Considered reflections are marked with a grey dot, Figure S8: Monocarboxylic and dicarboxylic fatty acids (lauric $\left(C_{12: 0}\right)$, palmitic $\left(C_{16: 0}\right)$, oleic $\left(C_{18: 1}\right)$, stearic $\left(C_{18: 0}\right)$, and pimelic $\left(C_{7}\right)$, suberic $\left(C_{8}\right)$, azelaic $\left(C_{9}\right)$, sebacic acids $\left(C_{10}\right)$, respectively) and glycerol peaks derived from Meth Prep analysis, Figure S9: Chart of plat reading results at OD45, where blue bars are absorbency reading for fish collagen and orange bars are for mammal collagen, Table S1: List of pigments found in distemper wall paintings in Norwegian stave churches. Table S1 is adapted from Table 3 in Olstad [1] which complies the findings from two studies using IR spectroscopy, SEM, microscopic examination, and/or microchemical analysis [2,3], Table S2: Color and pigment assumption for the decor in Heddal and Eidsborg, as cited in conservation reports [4-6], Table S3: Brief history of structural and interior changes of Heddal and Eidsborg, described in the conservation reports of Wedvik [4,5] and Solberg, Norsted, and Spaarschuh [6], Table S4: Sample description and sampling location in nave of Heddal and Eidsborg. Sample naming convention: name of church, sample category (1-treated with sturgeon glue, 2-untreated, 3-treated with sturgeon glue and in poor condition), letter signifying specific sample. See Figure S1 for visual representation of sampling location and specimen collected. See manuscript for map of sampling points (Figure 3), Table S5: Summary of cross-sectional sample's stratigraphy through microscopy analysis, where ND means not detected. See Figure S1 for corresponding microscopic image of samples, Table S6: Summary of common ESEM-EDS results of samples from Eidsborg and Heddal. Concentrations higher than 10 weight per cent (wt. \%) are considered major, whereas minor concentrations are between 1 and $10 \mathrm{wt} . \%$. Values lower than 1 are not listed. See following tables for wt.\% values, Table S7: EDS results of red layer, Table S8: EDS results of black layer and black particles, Table S9: EDS results of grey layer, Table S10: EDS results of orange layer, Table S11: EDS results of white layer, Table S12: Spectral interpretation of historic paint samples, with assignment of the main absorption bands according to the literature. $v=$ stretching; $v \mathrm{~s}=$ symmetric stretching; $v \mathrm{a}=$ asymmetric stretching; $\delta=$ bending; $\delta \mathrm{s}=$ symmetric bending; $\delta \mathrm{a}=$ asymmetric bend, Table S13: Signals assigned to FT-IR analysis of pigments. See Table S12 for attributions and references, Table S14. Signals assigned to FT-IR analysis of organic material (wood fractions, animal protein, and linseed oil). See Table S12 for attributions and references, Table S15: GC-MS testing configuration and parameters, Table S16: List of amino acid compositions from historic paints samples by GC-MS analysis (parts per million), Table S17: Fatty acid content (ppm) from paint samples analyzed, where ND denotes not detected or below the detection limit.

Author Contributions: Conceptualization, A.A.F.; investigation, A.A.F. and J.M.; resources, C.B.; data curation, A.A.F.; writing-original draft preparation, A.A.F., L.d.F., J.M. and F.A.; writingreview and editing, A.A.F., L.d.F., J.M., F.A. and C.B.; visualization, A.A.F., L.d.F., J.M. and F.A.; supervision, C.B.; project administration, C.B.; funding acquisition, C.B. All authors have read and agreed to the published version of the manuscript.

Funding: The sampling campaign undertaken on 27 September 2018 was funded by Norges Forskningsråd, Sustainable Management of heritage Buildings in a Long-term perspective (SyMBoL) Project No. 274749.

Institutional Review Board Statement: Not applicable.

Informed Consent Statement: Not applicable.

Data Availability Statement: All data is available within the manuscript and Supplementary Materials. 
Acknowledgments: The authors would like to express their gratitude to the Sustainable Management of heritage Buildings in a Long-term perspective (SyMBoL) Project (Norges Forskningsråd Project No. 274749) for their support during the sampling campaign. In addition, the authors would like to thank the partners of the SyMBoL project, in particular, our partners from NIKU: Anne Apalnes Ørnhøi, Tone Marie Olstad, Nina Kjølsen Jernæs, and Annika Haugen, as well as Michal Lukomski of the Getty Conservation Institute. Lastly, the authors would like to thank their colleague Di Wan from the Norwegian University of Science and Technology.

Conflicts of Interest: The authors declare that they have no conflict of interest.

\section{References}

1. Olstad, T.M. To the Glory of God and the Church's Adornment. In Preserving the Stave Churches. Craftmanship and Research; Bakken, K., Ed.; Pax Forlag: Riksantikvaren, Norway, 2016.

2. Anker, L. What is a stave church? In Preserving the Stave Churches. Craftmanship and Research; Bakken, K., Ed.; Pax Forlag: Riksantikvaren, Norway, 2016.

3. Olstad, T.M.; Solberg, K. Eight seventeenth-century decorative paintings-one painter? Stud. Conserv. 1998, 43, 175-179. [CrossRef]

4. Olstad, T.M.; Ørnhøi, A.A. 17th and 18th Century Distemper Decorative Paint in Wooden Churches in Norway Painting Technique, Materials and Alteration. Eur. J. Sci. Theol. 2017, 13, 113-126.

5. Olstad, T.M.; Solberg, K. Analytical Report, Centre for Art Technological Studies and Conservation (CATS); Copenhagen, Denmark, 2015; Available online: http://www.iperionch.eu/partners/centre-for-art-technological-studies-and-conservation-cats/ (accessed on 13 April 2021).

6. Wedvik, B. A 167 Heddal Stavkirke. Konsolidering Av Limfargedekor i Koret. Prosjektets Del 1: Nordvegg Og Apsis i Koret No. 49/2008; Norsk institutt for kulturminneforskning(NIKU): Oslo, Norwy, 2008.

7. Solberg, K.; Norsted, T.; Spaarschuh, C. Eidsborg Stavkirke. Konservering Av Veggmalerier Fra 1600-Tallet Og Paneler Fra Middelalderen No. 35/2007; Norsk institutt for kulturminneforskning(NIKU): Oslo, Norwy, 2007.

8. Wedvik, B. A 167 Heddal Stavkirke. Konsolidering Av Limfargedekor i Skip Og Sørvegg i Koret No. 121/2009; Norsk institutt for kulturminneforskning(NIKU): Oslo, Norwy, 2009.

9. Montagner, C.; Sanches, D.; Pedroso, J.; Melo, M.J.; Vilarigues, M. Ochres and earths: Matrix and chromophores characterization of 19th and 20th century artist materials. Spectrochim. Acta Part A Mol. Biomol. Spectrosc. 2013, 103, 409-416. [CrossRef] [PubMed]

10. Ortega-Avilés, M.; San-Germán, C.; Mendoza-Anaya, D.; Morales, D.; José-Yacamán, M. Characterization of mural paintings from Cacaxtla. J. Mater. Sci. 2001, 36, 2227-2236. [CrossRef]

11. Thomas, P.S.; Stuart, B.H.; McGowan, N.; Guerbois, J.P.; Berkahn, M.; Daniel, V. A study of ochres from an Australian aboriginal bark painting using thermal methods. J. Therm. Anal. Calorim. 2011, 104, 507-513. [CrossRef]

12. Matys Grygar, T.; Hradilová, J.; Hradil, D.; Bezdicka, P.; Bakardjieva, S. Analysis of earthy pigments in grounds of Baroque Paintings. Anal. Bioanal. Chem. 2003, 375, 1154-1160. [CrossRef] [PubMed]

13. Pérez-Villar, S.; Rubio, J.; Oteo, J.L. Study of color and structural changes in silver painted medieval glasses. J. Non-Cryst. Solids 2008, 354, 1833-1844. [CrossRef]

14. Serafima, S.; Duliu, O.G.; Manea, M.; Bojar, A.-V.; Costea, C.; Birgaoanu, D.; Barbu, O.-C. An xrf, xrd, ftir, ft raman, digital radiography and uv photography study of some classical pigments, primers and binders used in panel painting. Rom. Rep. Phys. 2019, 71, 201.

15. Elias, M.; Chartier, C.; Prévot, G.; Garay, H.; Vignaud, C. The Colour of Ochres Explained by Their Composition. Mater. Sci. Eng. B-Adv. Funct. Solid-State Mater. 2006, 127, 70-80. [CrossRef]

16. Čiuladienè, A.; Luckute, A.; Kiuberis, J.; Kareiva, A. Investigation of the chemical composition of red pigments and binding media. Chemija 2018, 29, 4. [CrossRef]

17. Monnard, A.; Lafon-Pham, D.; Garay, H. Influence of moisture content on colour of granular materials. Part I: Experiments on yellow ochre. Granul. Matter 2016, 18, 47. [CrossRef]

18. Juliá, C.G.; Bonafé, C.P. The use of natural earths in picture: Study and differentiation by thermal analysis. Thermochim. Acta 2004, 413, 185-192. [CrossRef]

19. Ortega, M.; Ascencio, J.; Reza, C.; Fernández, M.; López Luján, L.; Yacaman, M. Analysis of prehispanic pigments from ‘Templo Mayor' of Mexico City. J. Mater. Sci. 2001, 36, 751-756. [CrossRef]

20. Rosso, D.E.; Martí, A.P.; d'Errico, F. Middle Stone Age ochre processing and behavioural complexity in the horn of Africa: Evidence from porc-epic Cave, Dire Dawa, Ethiopia. PLoS ONE 2016, 11, e0164793. [CrossRef]

21. Colombini, M.P.; Andreotti, A.; Bonaduce, I.; Modugno, F.; Ribechini, E. Analytical strategies for characterizing organic paint media using gas chromatography/mass spectrometry. Acc. Chem. Res. 2010, 43, 715-727. [CrossRef] [PubMed]

22. Mazurek, J.; Svoboda, M.; Maish, J.; Kawahara, K.; Fukakusa, S.; Nakazawa, T.; Taniguchi, Y. Characterization of binding media in Egyptian Romano portraits using enzyme-linked immunosorbant assay and mass spectrometry. E-Preserv. Sci. 2014, 11, 76-83.

23. Mazurek, J.; Svoboda, M.; Schilling, M. GC/MS Characterization of Beeswax, Protein, Gum, Resin, and Oil in Romano-Egyptian Paintings. Heritage 2019, 2, 1960-1985. [CrossRef] 
24. Schilling, M.R.; Khanjian, H.P.; Souza, L.A.C. Gas Chromatographic Analysis of Amino Acids As Ethyl Chloroformate Derivatives. Part 1, Composition of Proteins Associated with Art Objects and Monuments. J. Am. Inst. Conserv. 1996, 35, 45-59. [CrossRef]

25. Schilling, M.R.; Khanjian, H.P. Gas chromatographic analysis of amino acids as ethyl chloroformate derivatives. Part 2, effects of pigments and accelerated aging on the identification of proteinaceous binding media. J. Am. Inst. Conserv. 1996, 35, 123-144. [CrossRef]

26. Schilling, M.R.; Khanjian, H.P. Gas chromatographic analysis of amino acids as ethyl chloroformate derivatives: III. Identification of proteinaceous binding media by interpretation of amino acid composition data. In Proceedings of the ICOM Committee for Conservation, 11th Triennial Meeting, Edinburgh, Scotland, 1-6 September 1996; pp. 211-219.

27. Casoli, A.; Musini, P.C.; Palla, G. Gas chromatographic-mass spectrometric approach to the problem of characterizing binding media in paintings. J. Chromatogr. A 1996, 731, 237-246. [CrossRef]

28. Casoli, A.; Musini, P.C.; Palla, G. A study for the characterization of binding media from medieval polychrome sculptures by gas chromatography-mass spectrometry. Chromatographia 1996, 42, 421-430. [CrossRef]

29. Castro, R.M.; Dome, M.; Marti, V.P.; Adelantado, J.G.; Reig, F.B. Study of binding media in works of art by gas chromatographic analysis of amino acids and fatty acids derivatized with ethyl chloroformate. J. Chromatogr. A 1997, 778, 373-381. [CrossRef]

30. Sutherland, K. Derivatisation using $\mathrm{m}$-(trifluoromethyl) phenyltrimethylammonium hydroxide of organic materials in artworks for analysis by gas chromatography-mass spectrometry: Unusual reaction products with alcohols. J. Chromatogr. A 2007, 1149, 30-37. [CrossRef] [PubMed]

31. Bonaduce, I.; Ribechini, E.; Modugno, F.; Colombini, M.P. Analytical Approaches Based on Gas Chromatography Mass Spectrometry (GC/MS) to Study Organic Materials in Artworks and Archaeological Objects. In Analytical Chemistry for Cultural Heritage; Mazzeo, R., Ed.; Springer: Cham, Switzerland, 2017; pp. 291-327.

32. Platania, E.; Streeton, N.L.W.; Lluveras-Tenorio, A.; Vila, A.; Buti, D.; Caruso, F.; Kutzke, H.; Karlsson, A.; Colombini, M.P.; Uggerud, E. Identification of green pigments and binders in late medieval painted wings from Norwegian churches. Microchem. J. 2020, 156, 104811. [CrossRef]

33. Thun, T.; Stornes, J.M.; Bartholin, T.S.; Svarva, H.L. Dendrochronology brings new life to the stave churches. Dating and material analysis. In Preserving the Stave Churches. Craftmanship and Research; Bakken, K., Ed.; Pax Forlag: Riksantikvaren, Norway, 2016.

34. Holen, L.D. Work Undertaken in the Stave Church Preservation Programme; Pax Forlag: Riksantikvaren, Norway, 2016.

35. Olstad, T.M.; Ørnhøi, A.A. Konsolidert limfargedekor i Stavkirkene-En Oversikt. Vurdering Av Størlim. Konsolidering Av Limfarge På Tre. Delprosjekt 1, NIKU Oppdragsrapport 62/2014; Norsk institutt for kulturminneforskning(NIKU): Oslo, Norwy, 2014.

36. Mills, J.S. The gas chromatographic examination of paint media. Part I. Fatty acid composition and identification of dried oil films. Stud. Conserv. 1966, 11, 92-107. [CrossRef]

37. Mills, J.; White, R. Analyses of Paint Media. Natl. Gallery Tech. Bull. 1983, 7, 65-67.

38. Colombini, M.P.; Modugno, F.; Ribechini, E. GC/MS in the Characterization of Lipids. In Organic Mass Spectrometry in Art and Archaeology; Colombini, M., Modugno, F., Eds.; John Wiley and Sons: London, UK, 2009; pp. 189-213.

39. Mazurek, J.; Schilling, M.; Chiari, G.; Heginbotham, A. Antibody assay to characterize binding media in paint. ICOM Comm. Conserv. 2008, 2, 678-685.

40. Gunasekaran, S.; Anbalagan, G.; Pandi, S. Raman and infrared spectra of carbonates of calcite structure. J. Raman Spectrosc. 2006, 37, 892-899. [CrossRef]

41. Gil, M.; Martins, M.R.; Carvalho, M.L.; Souto, C.; Longelin, S.; Cardoso, A.; Mirão, J.; Candeias, A.E. Microscopy and microanalysis of an extreme case of salt and biodegradation in 17th century wall paintings. Microsc. Microanal. 2015, 21, 606-616. [CrossRef]

42. López-Arce, P.; Gómez-Villalba, L.S.; Martínez-Ramírez, S.; De Buergo, M.Á.; Fort, R. Influence of relative humidity on the carbonation of calcium hydroxide nanoparticles and the formation of calcium carbonate polymorphs. Powder Technol. 2011, 205, 263-269. [CrossRef]

43. Rampazzi, L. Calcium oxalate films on works of art: A review. J. Cult. Herit. 2019, 40, 195-214. [CrossRef]

44. Madejová, J. FTIR techniques in clay mineral studies. Vib. Spectrosc. 2003, 31, 1-10. [CrossRef]

45. Müller, C.M.; Pejcic, B.; Esteban, L.; Delle Piane, C.; Raven, M.; Mizaikoff, B. Infrared attenuated total reflectance spectroscopy: An innovative strategy for analyzing mineral components in energy relevant systems. Sci. Rep. 2014, 4, 6764. [CrossRef]

46. Feller, R.L. Barium sulfate-natural and synthetic. In Artists' Pigments; A Handbook of Their History and Characteristics; National Gallery of Art: Washington, DC, USA, 1986; Volume 1, pp. 47-64.

47. De Silva, R. The problem of the binding medium particularly in wall painting. Archaeometry 1963, 6, 56-64. [CrossRef]

48. Colombini, M.P.; Fuoco, R.; Giacomelli, A.; Muscatello, B. Characterization of proteinaceous binders in wall painting samples by microwave-assisted acid hydrolysis and GC-MS determination of amino acids. Stud. Conserv. 1998, 43, 33-41. [CrossRef]

49. Invernizzi, C.; Rovetta, T.; Licchelli, M.; Malagodi, M. Mid and Near-Infrared Reflection Spectral Database of Natural Organic Materials in the Cultural Heritage Field. Int. J. Anal. Chem. 2018, 2018, 16. [CrossRef]

50. Moosavinejad, S.M.; Madhoushi, M.; Vakili, M.; Rasouli, D. Evaluation of degradation in chemical compounds of wood in historical buildings using FT-IR and FT-Raman vibrational spectroscopy. Maderas Cienc. Y Tecnol. 2019, 21, 381-392. [CrossRef]

51. Ganitis, V.; Pavlidou, E.; Zorba, F.; Paraskevopoulos, K.; Bikiaris, D. A post-Byzantine icon of St Nicholas painted on a leather support. Microanalysis and characterisation of technique. J. Cult. Herit. 2004, 5, 349-360. [CrossRef] 